\title{
Asymmetric Synthesis of Octahydroindoles via a Domino Robinson Annulation/5-Endo Intramolecular Aza-Michael Reaction
}

\author{
Claudio Parra, ${ }^{\dagger}$ Caroline Bosch, ${ }^{\dagger}$ Enrique Gómez-Bengoa, ${ }^{\ddagger}{\text { Josep Bonjoch, }{ }^{*} \dagger}^{\dagger}$ and Ben Bradshaw ${ }^{*}, \dagger, \S$ \\ †Laboratori de Química Orgànica, Facultat de Farmàcia, IBUB, Universitat de Barcelona, Av Joan XXIII s/n, 08028 Barcelona, Spain \\ ”Departamento de Química Orgánica I, Universidad del País Vasco, Manuel Lardizábal 3, 20018 San Sebastián, Spain
}

Supporting Information

ABSTRACT: A straightforward, two-step asymmetric synthesis of octahydroindoles has been developed on the basis of two complementary strategies: (i) an organocatalyzed Michael reaction followed by a tandem Robinson-aza-Michael double cyclization catalyzed by PS-BEMP, and (ii) a diastereoselective cyclization, which formally constitutes a remote 1,6 asymmetric induction mediated by PS-BEMP. This allowed the

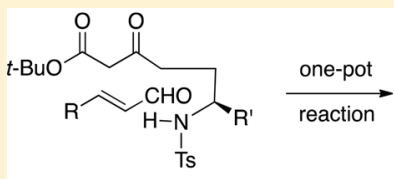

For $\mathrm{R}^{\prime}=\mathrm{H} \quad 7$ examples up to $95 \%$ ee For $\mathrm{R}=\mathrm{Bn} 4$ examples up to $>99 \% \mathrm{dr}$

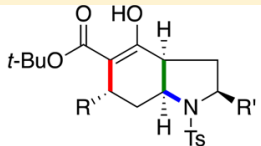

- Asymmetric organocatalysis or by diastereoselective remote induction - Robinson annulation

- 5-endo-trig intramolecular aza-Michael construction of complex octahydroindoles with up to four stereocenters, excellent enantioselectivities (up to 95\% ee), and complete diastereoselective control in a single-pot operation. DFT calculations were performed to understand the origin of this effect.

\section{INTRODUCTION}

The organocatalyzed construction of highly functionalized polycyclic nuclei in a one-pot operation from simple acyclic precursors has the potential to greatly shorten a synthetic sequence targeting complex natural products. ${ }^{1}$ Previously, we have developed an organocatalytic strategy toward decahydroquinolines that allowed the synthesis of an advanced common building block for a number of lycopodium alkaloids, such as lycoposerramine $\mathrm{Z}^{2}$ and cermizine $\mathrm{B}$. ${ }^{3}$ In both cases, the tandem reaction was instrumental in enabling highly efficient syntheses of these natural products. Looking to expand the potential of this methodology, it soon became apparent that the principles ${ }^{4}$ behind the reaction sequence, namely a $\beta$-keto ester, a tethered sulfonamide, and an enal engaging in a tandem Robinson aza-Michael reaction (see Figure 1), could be more general in scope, providing access to a range of different important nitrogen bicyclic nuclei in enantiopure form. Indeed, this proved to be the case and allowed us to achieve the first efficient synthetic entry to the morphan nucleus using organocatalysis from simple acyclic precursors. ${ }^{5}$ Here, we expand the scope of this strategy to include the octahydroindole unit, ${ }^{6}$ another privileged scaffold found in an extensive and diverse range of compounds (Figure 2). These include natural products such as aeruginosin $298-\mathrm{A},{ }^{7}$ lycorine, ${ }^{8}$ daphniyunnine $\mathrm{D}, 9$ neotuberostemonine, ${ }^{10}$ pharmaceutical products such as perindopril, ${ }^{11}$ and a number of proline analogue organocatalysts. ${ }^{12}$

While a number of methods have been developed to synthesize octahydroindoles in enantiopure form, using the chiral pool approach ${ }^{13}$ or asymmetric metal-catalyzed reactions, ${ }^{14}$ there are few previous approaches using aminocatalysis. $^{15}$

Detailed herein is the development of an organocatalysismediated synthesis of octahydroindoles from a noncyclic

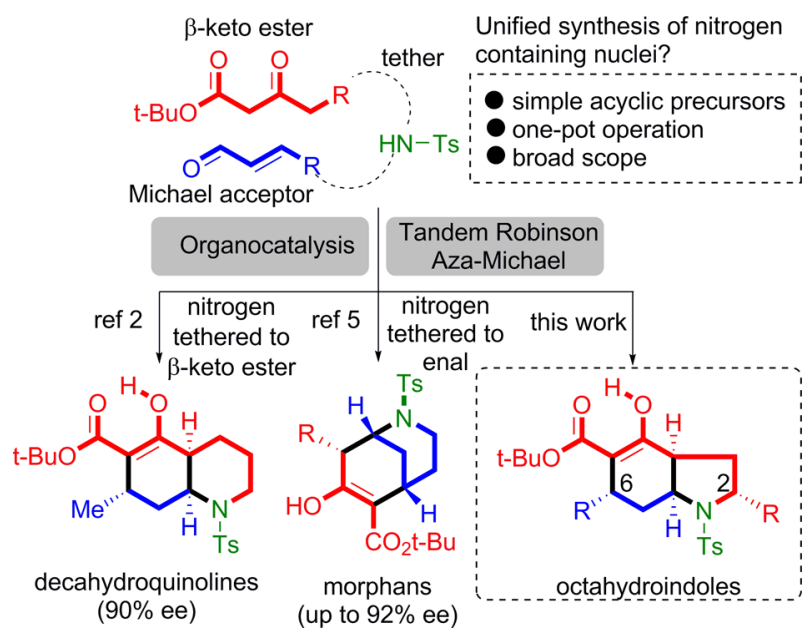

Figure 1. Unified strategy to important nitrogen-containing nuclei using an organocatalysis-initiated tandem Robinson aza-Michael reaction.

precursor. Notably, the process constitutes a rare example of an intramolecular aza-Michael reaction through a 5-endo-trig cyclization, ${ }^{16}$ the latter process being disfavored according to Baldwin's rules. ${ }^{17}$

\section{RESULTS AND DISCUSSION}

Preparation of the required starting material was achieved in a one-step manner by ring opening of the commercially available tosyl aziridines via the dianion of tert-butyl acetoacetate ${ }^{18}$ (eq

Special Issue: Heterocycles

Received: June 30, 2016 
<smiles>CC(C)C[C@H](NC(=O)[C@H](O)Cc1ccc(O)cc1)C(=O)N1C(C(=O)N[C@H](CO)CCCNC(=N)N)C[C@H]2CC[C@@H](O)C[C@H]21</smiles>

aeruginosin $298-A$

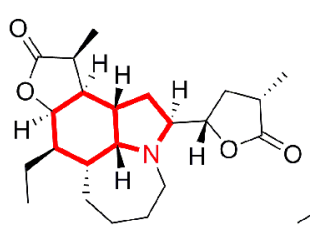

neotuberostemonine<smiles>CCCC(NC(CC)C(=O)N1C(C(=O)O)CC2CCCCC21)C(=O)O</smiles>

perindopril daphniyunnine $\mathrm{C}$

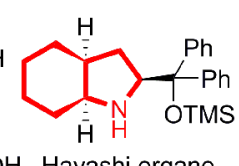

Hayashi organo-
catalyst analog

Figure 2. Diverse nitrogen-containing heterocycles with an embedded octahydroindole ring.

1). With the starting material $\mathbf{1 a}$ in hand, the nonasymmetric version of the tandem cyclization reaction was initially

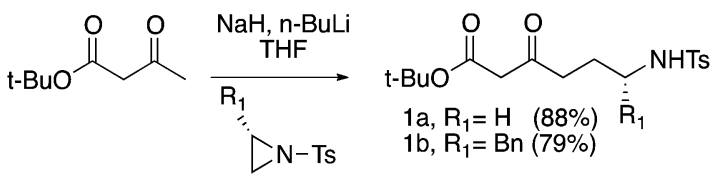

investigated. The key results are outlined in Table 1 . Satisfactorily, using the optimal conditions (crotonaldehyde $\mathrm{LiOH} \cdot \mathrm{H}_{2} \mathrm{O}$, $i-\mathrm{PrOH}, \mathrm{H}_{2} \mathrm{O}$ ) developed for the decahydroquinoline series gave the desired analogous octahydroindole product

Table 1. Screening of Tandem Cyclization Conditions Leading to Octahydroindole 2a

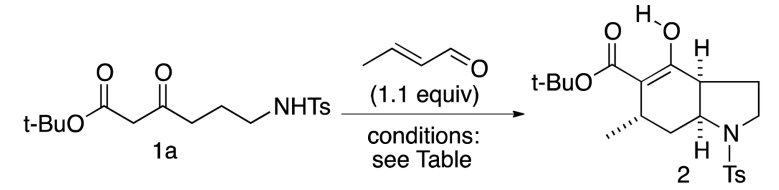

\begin{tabular}{|c|c|c|c|c|}
\hline $\begin{array}{c}\stackrel{\ominus}{\mathrm{OH}} \\
\mathrm{Bu} \stackrel{\oplus, \mathrm{Bu}}{\mathrm{N}^{\prime}} \\
\mathrm{Bu}^{\prime} \mathrm{Bu} \\
\text { (A) } \mathrm{TBAH}\end{array}$ & (B) $P S-B E M P$ & (C) Amberlyst-15 & (D) A & $\begin{array}{l}\stackrel{\mathrm{Me}}{\ominus} \mathrm{OH} \\
\mathrm{Me}^{1} \mathrm{Me} \\
\text { erlyst-26 }\end{array}$ \\
\hline entry & base (equiv) & solvent & time $(\mathrm{h})$ & yield $^{a}(\%)$ \\
\hline 1 & $\mathrm{LiOH} \cdot \mathrm{H}_{2} \mathrm{O}(1)^{b}$ & $i-\mathrm{PrOH}$ & 24 & 44 \\
\hline 2 & $t$-BuOK (0.3) & $t-\mathrm{BuOH}$ & 24 & $15^{c}$ \\
\hline 3 & $\mathrm{~A}^{d}(0.3), \mathrm{KOH}(\mathrm{aq})$ & $\mathrm{Et}_{2} \mathrm{O} / \mathrm{THF}$ & 72 & 57 \\
\hline 4 & $\mathbf{B}^{e}(0.1), \mathbf{C}(2)$ & $\mathrm{CH}_{2} \mathrm{Cl}_{2}$ & 72 & \\
\hline 5 & B (1), C (2) & $i-\mathrm{PrOH}$ & 24 & $56^{f}$ \\
\hline 6 & B (1), C (2) & $t-\mathrm{BuOH}$ & 24 & 45 \\
\hline 7 & B (1) & $i-\mathrm{PrOH}$ & 24 & 42 \\
\hline 8 & B (1) & $i-\mathrm{PrOH}$ & 72 & 68 \\
\hline 9 & B $(0.1)$ & $i-\mathrm{PrOH}$ & 72 & 54 \\
\hline 10 & D (1) & $i$-PrOH & 24 & 43 \\
\hline
\end{tabular}

${ }^{a}$ Yield refers to the products isolated by flash chromatography. ${ }^{b} 10$ equiv of $\mathrm{H}_{2} \mathrm{O}$ added. ${ }^{c}$ Significant amounts of the noncyclized cyclohexenone were also obtained ( $40 \%){ }^{d}$ TBAH refers to $40 \% n$ $\mathrm{Bu}_{4} \mathrm{NOH}$ in $\mathrm{H}_{2} \mathrm{O}$. ${ }^{e} \mathrm{PS}$-BEMP refers to polymer-supported 2-(tertbutylimino)-2-(diethylamino)-1,3-dimethylperhydro-1,3,2-diazaphosphorine. ${ }^{f}$ Isolated as a mixture of esters by a solvent transesterification process.

2a, which maintained the all-cis stereochemistry (Table 1, entry 1). The moderate yield led us to evaluate other conditions ${ }^{4}$ such as $t$ - $\mathrm{BuOK}$ in $t$ - $\mathrm{BuOH}^{19}$ (entry 2 ), which gave just $15 \%$ of $\mathbf{2 a}$, with the rest (40\%) recovered as the uncyclized cyclohexenone. The use of $n-\mathrm{Bu}_{4} \mathrm{NOH} / \mathrm{KOH}^{20}$ gave similar results, but it was found that if the reaction was lengthened to $72 \mathrm{~h}$ the desired product could be obtained in moderately good yield (entry 3 ). We also evaluated the use of PS-BEMP with Amberlyst-15 (B and C, Table 1) under the concept of siteisolated reactivity using the conditions reported by Dixon. ${ }^{21}$ However, only traces of the Michael product were observed (entry 4). Increasing the amount of PS-BEMP to 1 equiv gave a good yield, but significant quantities of the transesterification products were also isolated, presumably catalyzed by the acid resin (entry 5). Switching the solvent to $t$ - $\mathrm{BuOH}$ gave a slightly less efficient conversion, but with no transesterification side products (entry 6). However, using PS-BEMP alone in $i-\mathrm{PrOH}$ gratifyingly gave $\mathbf{2 a}$ in moderate yield (entry 7 ), while extending the reaction to $72 \mathrm{~h}$ gave the best yield so far of $68 \%$ (entry 8 ). Reducing the amount of PS-BEMP to catalytic quantities was feasible, albeit at a cost of slightly reducing the yield (entry 9). We also evaluated the more economical Amberlyst-26 resin, but this did not perform so well, with the yield dropping to $43 \%$ (entry 10 ). ${ }^{22}$

The relative stereochemistry of rac-2, which is the same for all compounds synthesized in this series (see below), was elucidated by 2D NMR spectra (COSY, HSQC, NOESY). Octahydroindole 2a shows a preferred conformation in which the $\mathrm{C} 7-\mathrm{C} 7 \mathrm{a}$ bond of the carbocyclic ring adopts an axial disposition with respect to the nitrogen-containing ring to avoid the allylic strain with the sulfonamide group. The key

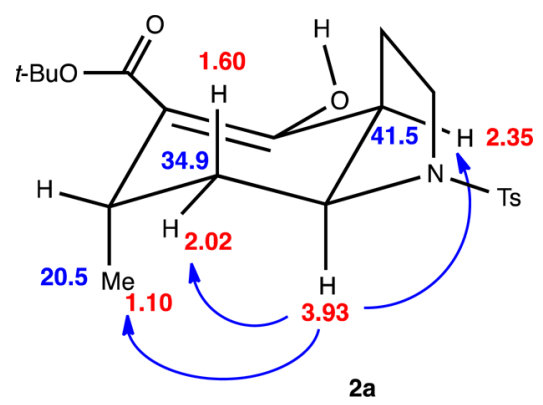

Figure 3. Characteristic NMR data and selected NOEs of hydroindole 2a.

evidence for the structure depicted in Figure 3 was found in the ${ }^{1} \mathrm{H}$ NMR coupling pattern for $\mathrm{H}-7 \mathrm{ax}$, which appears as a triplet of doublets $(J=12.8,5.2 \mathrm{~Hz})$. This coupling pattern is only compatible with an axially disposed location of the methyl group at C-6. Moreover, the axial proton $\mathrm{H}-7 \mathrm{a}$ is strongly coupled with only one adjacent axial proton. Hence, its resonance signal appears deceptively as a doublet $(J=12.8 \mathrm{~Hz})$ of other doublets $(J=8.0,4.8 \mathrm{~Hz})$. This structural elucidation is fully confirmed by the NOE contacts observed for $\mathrm{H}-7$ a (Figure 3).

In order to render the initial Michael addition step in the tandem Robinson/aza-Michael reaction enantioselective, we applied the conditions developed in the decahydroquinoline series $^{2}$ (using the Hayashi-Palomo catalyst $3{ }^{23} \mathrm{LiOAc}$ as an additive, and toluene as a solvent) to see if the octahydroindole series followed the same reactivity pattern. A brief solvent 
screen for the organocatalytic step proved this to be the case, so toluene was again selected as the solvent of choice based on ee and yield. With the organocatalytic step sufficiently optimized, the use of different cyclization conditions for the tandem reaction were then evaluated. With no clear winner for the base for the cyclization step, we decided to test all the conditions that had given good results (see Table 1).

The use of $\mathrm{LiOH}$ gave $82 \%$ ee (Table 2, entry 1 ), which was increased to $87 \%$ by lowering the reaction temperature (entry

Table 2. Organocatalyzed Michael Reaction/Aldol/

Intramolecular Aza-Michael Process Leading to Octahydroindole 2a<smiles>C/C=C/C=O</smiles><smiles>O=[PH](=O)(O)C(c1ccccc1)(c1ccccc1)C1CCCN1</smiles>

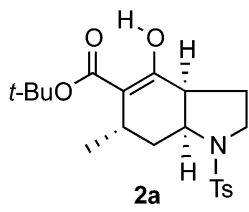

\begin{tabular}{|c|c|c|c|c|c|}
\hline entry & solvent & $\stackrel{\text { temp }}{\left({ }^{\circ} \mathrm{C}\right)}$ & cyclization conditions $^{a}$ & $\begin{array}{c}\text { yield }^{b} \\
(\%)\end{array}$ & $\begin{array}{l}\text { ee } \\
(\%)\end{array}$ \\
\hline 1 & toluene & $\mathrm{rt}$ & $\begin{array}{l}\mathrm{LiOH} \cdot \mathrm{H}_{2} \mathrm{O}\left(\mathrm{T}^{c}{ }^{c}: \text { entry }\right. \\
\text { 1) }\end{array}$ & 51 & 82 \\
\hline 2 & free & rt & $\mathrm{T} 1:$ entry 1 & 7 & 14 \\
\hline 3 & $\mathrm{MeOH}$ & $\mathrm{rt}$ & $\mathrm{T} 1:$ entry 1 & 40 & 77 \\
\hline 4 & $\mathrm{CH}_{2} \mathrm{Cl}_{2}$ & $\mathrm{rt}$ & $\mathrm{T} 1$ : entry 1 & 27 & 85 \\
\hline 5 & toluene & 0 & $\begin{array}{l}\mathrm{LiOH} \cdot \mathrm{H}_{2} \mathrm{O} \text {, (T1: entry } \\
\text { 1) }\end{array}$ & 55 & 87 \\
\hline 6 & toluene & 0 & $t$-BuOK (T1: entry 2) & 61 & 73 \\
\hline 7 & toluene & 0 & $\mathrm{KOH}, \mathbf{A},(\mathrm{T} 1:$ entry 3$)$ & 51 & 94 \\
\hline 8 & toluene & 0 & B (T1: entry 8) & 50 & 90 \\
\hline 9 & toluene & 0 & B (T1: entry 9) & 29 & 87 \\
\hline 10 & toluene & 0 & D (T1:entry 10) & 44 & 84 \\
\hline
\end{tabular}

${ }^{a}$ Reactions were carried out with 1.1 equiv of crotonaldehyde and 0.5 equiv of LiOAc, as an additive, and the reaction time for the first step (i) was $24 \mathrm{~h}$. The second step (ii) was carried out with the base indicated in $i$-PrOH for $72 \mathrm{~h}$. ${ }^{b}$ Yield refers to the products isolated by flash chromatography. ${ }^{c} \mathrm{~T} 1$ refers to reaction conditions in Table 1.
5). We were surprised to observe that the choice of base was indeed crucial for obtaining good enantioselectivities. Compared to $\mathrm{LiOH}$, the use of $t$-BuOK resulted in a quite considerable reduction of the ee to $73 \%$ (entry 6 ), while the use of $\mathrm{KOH}$ with $\mathrm{TBAH}$ under biphasic conditions gave an improved ee of $94 \%$ (entry 7). The treatment with PS-BEMP ( 1 equiv) performed almost equally well, giving $90 \%$ ee (entry 8). Using catalytic PS-BEMP conditions, the ee dropped slightly to $87 \%$, and the yield was significantly reduced (entry 9). The use of the Amberlyst A26 resin resulted in a moderate $84 \%$ ee and also a moderate yield. While the $\mathrm{KOH}, \mathrm{TBAH}$ conditions (entry 7) were the best in terms of enantioselectivity, we chose PS-BEMP (entry 8) as the optimum conditions based on the following criteria: (i) the reaction setup and work was significantly easier, requiring simple addition and filtration, and (ii) we observed that $\mathrm{KOH}, \mathrm{TBAH}$ was less effective when the enal substituent was not a methyl group. The absolute configuration proposed for octahydroindole $(+)-2 \mathrm{a}$ is based on the accepted mechanism of organocatalyzed Michael addition of $\beta$-keto esters upon enals ${ }^{24}$ as well as the absolute stereochemistry reported in the related process leading to enantiopure decahydroquinolines. ${ }^{3}$

To test the scope of the reaction, a range of enals were examined (Scheme 1). It should be noted that in cases where the enal was not volatile, it was necessary to reduce any excess material by hydrogenation before adding the base to initiate the tandem cyclization reaction. Aliphatic enals gave the corresponding octahydroindoles $\mathbf{2} \mathbf{b}$ and $\mathbf{2} \mathbf{c}$ with good enantioselectivities ( $87 \%$ and $92 \%$ ee, respectively). The enal bearing a free hydroxyl group efficiently gave $2 \mathrm{~d}$ under racemic conditions but did not evolve under organocatalysis due to the formation of a stable heminal species. The reaction also generally performed well when enals with a $\beta$-aromatic substituent were used, giving $\mathbf{2 e}$ (phenyl group), 2f ( $p$ chlorophenyl) or $\mathbf{2 g}$ ( $p$-methoxyphenyl), the latter bearing an electron-donating substituent, and all with excellent enantioselectivities.

Since many octahydroindole products bear a substituent at the 2-position, we were interested in examining the effect of

\section{Scheme 1. Scope of the Organocatalyzed Reaction ${ }^{a}$}

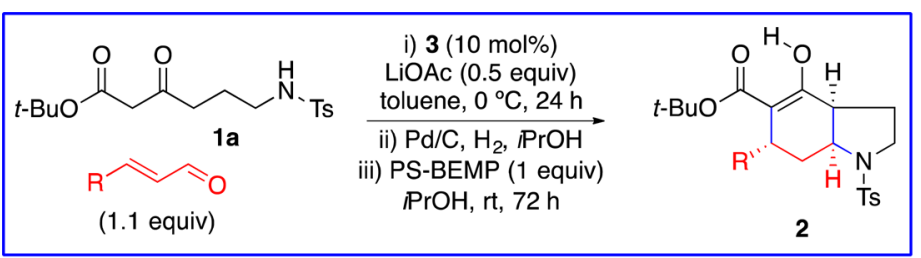

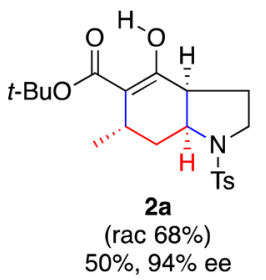

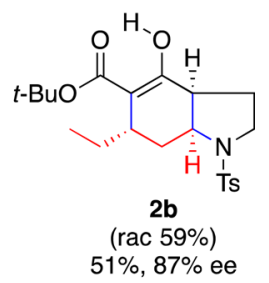

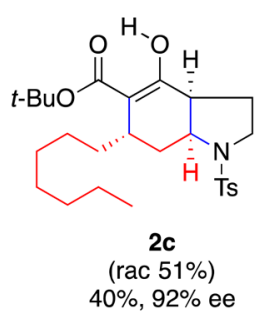
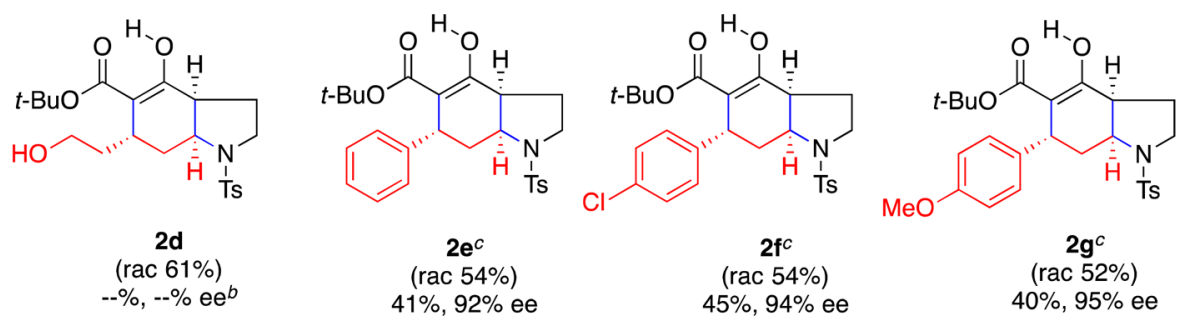

\footnotetext{
${ }^{a}$ Each compound was prepared initially in racemic form using only the conditions of part iii of the transformation of $\mathbf{1 a}$ to $2 \mathbf{b}-\mathbf{g}$. ${ }^{b}$ Organocatalytic conditions did not lead to any significant quantity of coupled product. ${ }^{c}$ Excess unreacted nonvolatile enal was converted by hydrogenation to the corresponding aldehyde (see procedure $\mathrm{C}$ in the Experimental Section).
} 
Table 3. Scope of the Domino Process from Enantiopure Acyclic $\beta$-Keto Ester $1 \mathrm{~b}$

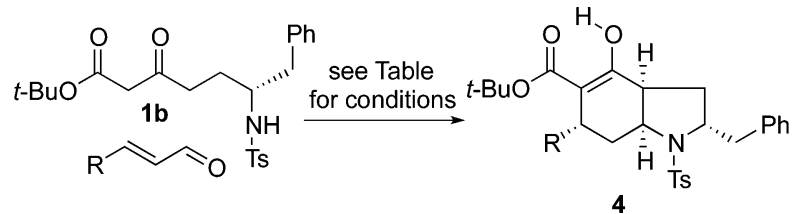

\begin{tabular}{|c|c|c|c|c|}
\hline entry $^{a}$ & $\mathrm{R}$ & compd & conditions & yield (\%) \\
\hline 1 & $\mathrm{Me}$ & $4 a$ & PS-BEMP & 44 \\
\hline 2 & $\mathrm{Me}$ & $4 a$ & $\mathrm{LiOH}_{\mathrm{H}} \mathrm{H}_{2} \mathrm{O}$ & 60 \\
\hline 3 & $\mathrm{Me}$ & $4 a$ & Amberlyst A-26 & 29 \\
\hline 5 & $\mathrm{Me}$ & $4 a$ & BEMP & 24 \\
\hline 6 & $\mathrm{Me}$ & $4 a$ & $3^{b}$ then PS-BEMP & 27 \\
\hline 7 & $\mathrm{Me}$ & $4 a$ & ent $-3^{b}$ then PS-BEMP & $c$ \\
\hline 8 & $\mathrm{Me}$ & $4 a$ & PS-BEMP (0.3) & 45 \\
\hline 9 & $\mathrm{Me}$ & $4 a$ & PS-BEMP $(0.3)^{d}$ & 36 \\
\hline 10 & hept & $4 b$ & PS-BEMP & 28 \\
\hline 11 & $\left(\mathrm{CH}_{2}\right)_{2} \mathrm{OH}$ & $4 c$ & PS-BEMP & 30 \\
\hline 12 & $\mathrm{Ph}$ & $4 d$ & PS-BEMP ${ }^{e}$ & 43 \\
\hline
\end{tabular}

${ }^{a}$ Unless otherwise stated, reactions were carried out with 1 equiv of base in $i$-PrOH for $72 \mathrm{~h} .{ }^{b}$ Conditions for the organocatalytic step were carried out as in Table 2 , entry $8 .{ }^{c} \mathrm{~A}$ mixture of various unidentified compounds was obtained with only traces of $4 \mathrm{a}$. ${ }^{d} 10$ equiv of $\mathrm{H}_{2} \mathrm{O}$ was added. ${ }^{e}$ The use of $\mathrm{LiOH} \cdot \mathrm{H}_{2} \mathrm{O}$ gave significantly lower yields when $\mathrm{R}$ was $>\mathrm{Me}$. placing a corresponding substituent in the $\beta$-keto ester starting material $\alpha$ to the nitrogen (Table 3). We began by taking $\alpha$ substituted $\beta$-keto ester $\mathbf{1 b}$ and reacting it under the racemic conditions (PS-BEMP, $i$-PrOH). Notably, the isolation of compound $4 \mathrm{a}$ indicated that the incorporation of a stereogenic center at the $\alpha$-position of the nitrogen atom (i.e., a benzyl group) caused an effective remote 1,6-asymmetric induction. ${ }^{25}$ The stereostructure of $\mathbf{4 a}$ was assigned on the basis that the set of signals in its NMR spectra $\left({ }^{1} \mathrm{H}\right.$ and $\left.{ }^{13} \mathrm{C}\right)$ showed a close correlation with those observed in 2 . Thus, considering that the pattern of chemical shifts and coupling constants for H-3a, H-6, $\mathrm{H}-7$, and $\mathrm{H}-7 \mathrm{a}$ in $\mathbf{4 a}$ was the same as in $\mathbf{2 a}$, a stereostructure analogous to that depicted in Figure 1 but having the benzyl substituent at $\mathrm{C}-2$ was assigned to $\mathbf{4 a}$ with the all-cis configuration.

To see if the above asymmetric induction was an effect unique to PS-BEMP, the previously evaluated bases were analyzed, and the product found in each case was $\mathbf{4 a}$ (Table 3). The effect of using the organocatalyst 3 in the initial Michael step was then examined. While the matched organocatalyst (-)-3 gave a similar result regarding the all-cis stereochemistry, ent-3 failed to provide the opposite stereochemistry at C-6.

To explore the scope of the reaction, some different unsaturated aldehydes were used in the coupling reaction. As can be seen in Table 3, the reaction worked with a variety of substrates, leading to the octahydroindoles $4 \mathbf{b}-\mathbf{d}$ in a nonoptimized moderate yield.

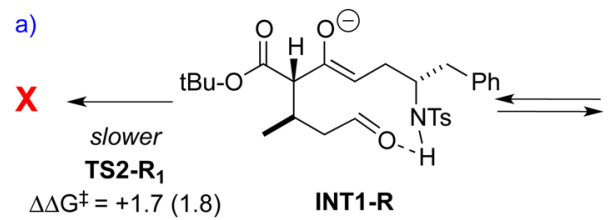<smiles>CC(C)COC=CCC(Cc1ccccc1)Cc1ccccc1</smiles><smiles>CC(C)COC(=O)C1C(=O)C(C[C@H](N)Cc2ccccc2)=CC[C@H]1C</smiles>
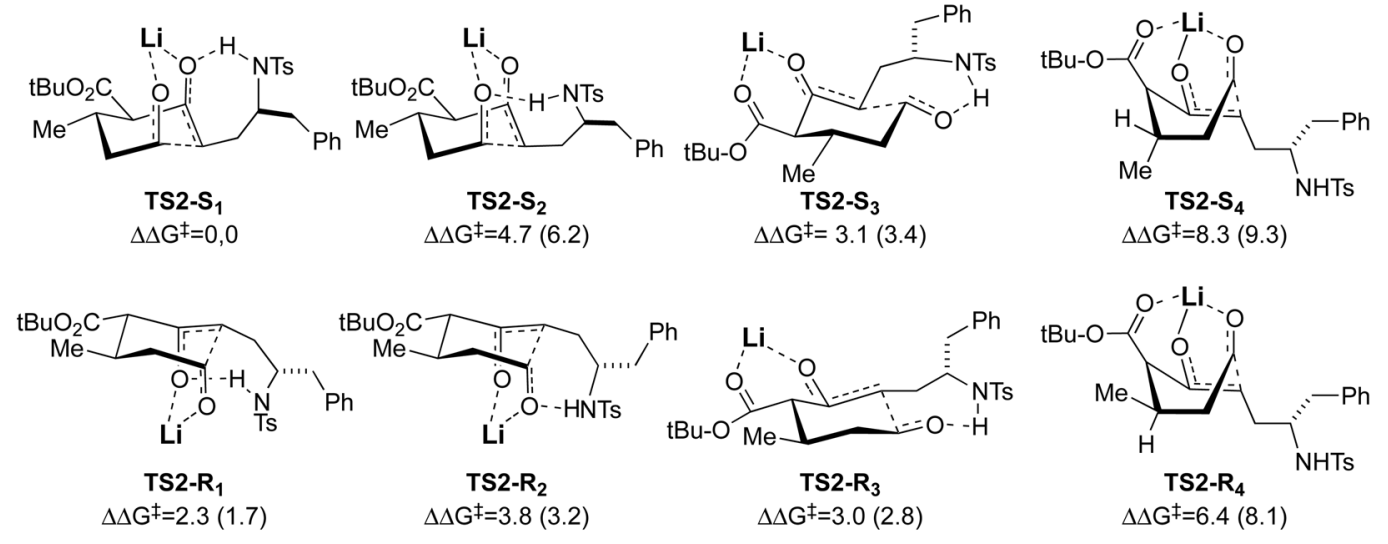

b)

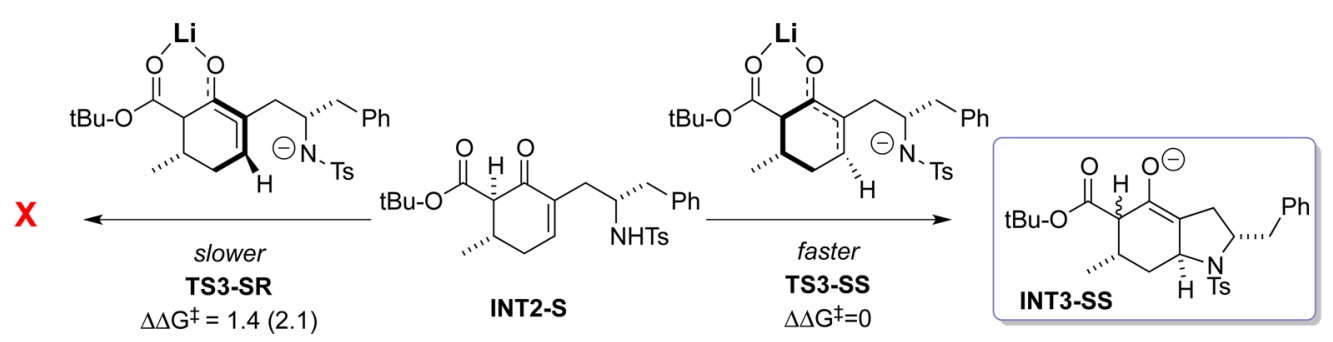

Figure 4. Proposed mechanism for the diastereoselective synthesis of enantiopure octahydroindoles 4: (a) Robinson annulation; (b) intramolecular aza-Michael. Relative activation Gibbs Free energies computed at M062x/6-311+G** (CPCM = water) level of theory. Value in parentheses corresponds to $\mathrm{wB} 97 \mathrm{xD} / 6-311+\mathrm{G}^{* *}$ (water) single points. 
Next, we conducted DFT calculations ${ }^{26}$ in order to shed light on the unexpected complete diastereoselectivity exerted by the benzyl substituent on the bicycle formation. At first sight, any of the $\mathrm{C}-\mathrm{C}$ or $\mathrm{C}-\mathrm{N}$ bond-forming processes is a potential candidate to be the stereodetermining transformation. We thus considered all possibilities, starting with the initial Michael addition of the dicarbonylic compound to cronotaldehyde (TS1, see the SI), to form INT1-R and INT1-S (Figure 4), which, as expected, turned out to be nonselective. The absence of interaction between the forming $\mathrm{C}-\mathrm{C}$ bond and the stereogenic center $\alpha$ to the nitrogen atom might be behind the observed lack of stereocontrol. The fact that TS1 is nonselective undoubtedly means that INT1-R and INT1-S must be in equilibrium (Curtin-Hammett conditions) prior to the stereodetermining step, which we hypothesized to be TS2 (Figure 4a). A number of TS2 structures were located, showing different $\mathrm{Li}$ cation and $\mathrm{H}$-bond $(\mathrm{TsNH})$ activation modes of the ring formation process. Gratifyingly, the transition state lowest in energy (TS2-S $_{1}$ corresponds to the formation of the $S$ epimer, which is the one experimentally observed. In this structure $\left(\mathbf{T S} 2-S_{1}\right)$, the lithium atom is bonded to the two reacting oxygen units (enolate and aldehyde) and the $\mathrm{NH}$ of the tosyl group is hydrogen bonding the enolate oxygen. Any other $\mathrm{Li} / \mathrm{NH}$ bond combination $\left(\mathbf{T S 2}-\mathbf{S}_{\mathbf{2}}\right.$ to $\mathbf{T S 2}-\mathbf{S}_{4}$, Figure $4 \mathrm{a}$ ) is not so favorable in terms of energy. Similar activation modes can be found in the transition states leading to the $R$ epimer, TS2- $\mathbf{R}_{\mathbf{1}}$ being the lowest one, but their energies are at least $1.7-2.0 \mathrm{kcal} / \mathrm{mol}$ larger than those of the $S$ isomer, in agreement with the experimental selectivity data. We hypothesized that the reason for the energy difference between TS2-S 1 and TS2-R $\mathbf{R}_{1}$ might be the tight character of these tricyclic structures, where the steric interaction of the benzyl group with the rest of the molecule gains significance.

We also studied the diastereoselectivity of the second ring formation by attack of the nitrogen atom to INT2-S. The most favorable transition states located were TS3-SR and TS3-SS (Figure $4 \mathrm{~b}$ ), and the comparison of their relative Gibbs free energies is again in agreement with the experimental results, predicting the formation of the $S S$ adduct. In both diastereoisomers, the lithium cation is bonded to the oxygens of the dicarbonylic system, activating the enone (INT2-S) toward the nucleophilic attack of the tosylamine.

In conclusion, an effective, enantioselective, organocatalytic route to polyfunctionalized octahydroindoles was developed using a one-pot sequence, further expanding the potential scope of the organocatalyzed Robinson/aza-Michael reaction for the rapid construction of important natural product nuclei. The further application of this methodology to synthesize other azabicyclic scaffolds and its use in total synthesis is currently in progress in our laboratory. Moreover, a diastereoselective route starting from commercially available enantiopure aziridine was developed, in which a 1,6-remote control induction was observed in a process leading to enantiopure 2,4,5,6tetrasubstituted hydroindoles.

\section{EXPERIMENTAL SECTION}

General Methods. All reactions were carried out under an argon atmosphere with dry, freshly distilled solvents under anhydrous conditions. Analytical thin-layer chromatography was performed on $\mathrm{SiO}_{2}$ (silica gel $60 \mathrm{~F}_{254}$ ), and the spots were located with $1 \%$ aqueous $\mathrm{KMnO}_{4}$. Chromatography refers to flash chromatography and was carried out on $\mathrm{SiO}_{2}$ (silica gel 60 ACC, 35-75 $\mu \mathrm{m}, 230-240$ mesh). Drying of organic extracts during workup of reactions was performed over anhydrous $\mathrm{Na}_{2} \mathrm{SO}_{4}$. Chemical shifts of ${ }^{1} \mathrm{H}$ and ${ }^{13} \mathrm{C}$ NMR spectra are reported in $\mathrm{ppm}$ downfield $(\delta)$ from $\mathrm{Me}_{4} \mathrm{Si}$. All NMR data assignments are supported by gCOSY and gHSQC experiments. The triphenylsilyl catalyst 3 was prepared by a literature procedure. ${ }^{23}$

tert-Butyl 6-(4-Methylphenylsulfonamido)-3-oxohexanoate (1a). ${ }^{16}$ THF $(40 \mathrm{~mL})$ was added to $\mathrm{NaH}(60 \%$ in mineral oil) $(0.37 \mathrm{~g}, 9.22 \mathrm{~mol})$, and the resulting suspension was cooled $0{ }^{\circ} \mathrm{C}$. tertButyl acetoacetate $(0.73 \mathrm{~g}, 4.61 \mathrm{mmol})$ was added dropwise, and the colorless solution was stirred at $0{ }^{\circ} \mathrm{C}$ for $10 \mathrm{~min}$. Then $n$-butyllithium $(1.9 \mathrm{~mL}, 2.6 \mathrm{M}$ in hexanes, $4.94 \mathrm{mmol}$ ) was added dropwise, and the resulting orange solution was stirred at $0{ }^{\circ} \mathrm{C}$ for an additional $10 \mathrm{~min}$. $N$-Tosylaziridine $(1.00 \mathrm{~g}, 5.07 \mathrm{mmol})$ in THF $(5 \mathrm{~mL})$ was added (the color of the dianion faded on addition of the aziridine), and the reaction mixture was stirred at room temperature for $15 \mathrm{~min}$. The mixture was quenched with aqueous $\mathrm{NH}_{4} \mathrm{Cl}(2 \mathrm{~mL})$ plus $5 \mathrm{~mL}$ of water $(5 \mathrm{~mL})$ and diluted with $\mathrm{Et}_{2} \mathrm{O}(15 \mathrm{~mL})$. The organic phase was washed with water, dried, and concentrated. Purification by chromatography (hexane to hexane/EtOAc 1:1) gave $\beta$-keto ester 1a $(1.44 \mathrm{~g}, 88 \%)$ as a light colored oil: ${ }^{1} \mathrm{H} \mathrm{NMR}\left(\mathrm{CDCl}_{3}, 400 \mathrm{MHz}\right) \delta$ $1.44\left(\mathrm{~s}, 9 \mathrm{H}, \mathrm{CH}_{3}\right), 1.75$ (qd, $\left.J=6.4,0.8 \mathrm{~Hz}, 2 \mathrm{H}, \mathrm{CH}_{2}\right), 2.40(\mathrm{~s}, 3 \mathrm{H}$, $\left.\mathrm{CH}_{3}\right), 2.54\left(\mathrm{td}, J=6.8,1.2 \mathrm{~Hz}, 2 \mathrm{H}, \mathrm{CH}_{2}\right), 2.92(\mathrm{qd}, J=6.8,1.2 \mathrm{~Hz}$, $\left.2 \mathrm{H}, \mathrm{CH}_{2}\right), 3.31\left(\mathrm{~s}, 2 \mathrm{H}, \mathrm{CH}_{2}\right), 4.76(\mathrm{br}, 1 \mathrm{H}, \mathrm{NH}), 7.28(\mathrm{~d}, 2 \mathrm{H}, m-$ $\mathrm{ArH}), 7.71$ (d, 2H, o-ArH); ${ }^{13} \mathrm{C}$ NMR $\left(100 \mathrm{MHz}, \mathrm{CDCl}_{3}\right) \delta 21.4$ $\left(\mathrm{ArCH}_{3}\right), 23.1$ (C-5), $27.8\left(\mathrm{CH}_{3}\right), 39.4$ (C-4), 42.2 (C-6), 50.4 (C-2), 82.1 (C), 127.1 (o-Ar), 129.7 (m-Ar), 136.9 (p-Ar), 143.3 (ipso-Ar), 166.6 (C-3), 202.9 (CO); HRMS (ESI-TOF) $\mathrm{m} / z\left[\mathrm{M}+\mathrm{NH}_{4}\right]^{+}$calcd for $\mathrm{C}_{17} \mathrm{H}_{29} \mathrm{~N}_{2} \mathrm{O}_{5} \mathrm{~S} 373.1792$, found 373.1798 .

tert-Butyl (S)-6-((4-Methylphenyl)sulfonamido)-3-oxo-7-phenylheptanoate $(1 \mathrm{~b})$. THF $(10 \mathrm{~mL})$ was added to $\mathrm{NaH}(60 \%$ mineral oil, $113 \mathrm{mg}, 2.84 \mathrm{mmol}$ ), and the resulting suspension was cooled to 0 ${ }^{\circ} \mathrm{C}$. tert-Butyl acetoacetate $(144 \mathrm{mg}, 0.949 \mathrm{mmol})$ was added dropwise, and the colorless solution was stirred at $0{ }^{\circ} \mathrm{C}$ for $10 \mathrm{~min}$. Then $n$ butyllithium ( $385 \mu \mathrm{L}$ of $2.6 \mathrm{M}$ in hexanes, $1.00 \mathrm{mmol}$ ) was added dropwise, and the orange solution was stirred at $0{ }^{\circ} \mathrm{C}$ for an additional $10 \mathrm{~min}$. (S)-(+)-2-Benzyl-1-( $p$-tolylsulfonyl)aziridine $(1.04 \mathrm{mmol}, 300$ $\mathrm{mg}$ ) in THF $(1 \mathrm{~mL})$ was added (the color of the dianion faded immediately on addition of the aziridine), and the reaction mixture was stirred at room temperature for $15 \mathrm{~min}$. The mixture was quenched with aqueous $\mathrm{NH}_{4} \mathrm{Cl}(1 \mathrm{~mL})$ plus water $(3 \mathrm{~mL})$ and diluted with $\mathrm{Et}_{2} \mathrm{O}(7 \mathrm{~mL})$. The organic phase was washed with water, dried, and concentrated. Purification by chromatography (hexane to hexane/ EtOAc $1: 1)$ gave $\beta$-keto ester $\mathbf{1 b}(334 \mathrm{mg}, 79 \%)$ as a yellow oil: ${ }^{1} \mathrm{H}$ $\operatorname{NMR}\left(\mathrm{CDCl}_{3}, 400 \mathrm{MHz}\right) \delta 1.46\left(\mathrm{~s}, 9 \mathrm{H}, \mathrm{CH}_{3}\right), 1.51-1.61(\mathrm{~m}, 1 \mathrm{H}, \mathrm{H}-$ 5), $1.78-1.86(\mathrm{~m}, 1 \mathrm{H}, \mathrm{H}-5), 2.41\left(\mathrm{~s}, 3 \mathrm{H}, \mathrm{CH}_{3}\right), 2.52-2.65(\mathrm{~m}, 4 \mathrm{H}$, $2 \mathrm{CH}_{2}$ ), 3.29 (dd, $J=3.2 \mathrm{~Hz}, 2 \mathrm{H}, \mathrm{CH}_{2}$ ), 3.40-3.49 (m, $\left.1 \mathrm{H}, \mathrm{H}-6\right), 4.63$ (br, $1 \mathrm{H}, \mathrm{NH}), 6.94(\mathrm{dd}, J=7.6,2.8 \mathrm{~Hz}, 2 \mathrm{H}, \mathrm{Ph}), 7.17-7.20(\mathrm{~m}, 3 \mathrm{H}$, $\mathrm{Ph}), 7.24(\mathrm{~d}, J=8.4 \mathrm{~Hz}, 2 \mathrm{H}, m-\mathrm{ArH}), 7.64(\mathrm{~d}, J=8.4 \mathrm{~Hz}, 2 \mathrm{H}, o-\mathrm{ArH})$; ${ }^{13} \mathrm{C}$ NMR $\left(100 \mathrm{MHz}, \mathrm{CDCl}_{3}\right) \delta 21.5\left(\mathrm{ArCH}_{3}\right), 27.9(\mathrm{C}-5), 28.0$ $\left(\mathrm{CH}_{3}\right), 38.9$ (C-4), $41.8\left(\mathrm{CH}_{2}\right), 50.5$ (C-2), 54.3 (C-6), $81.9(\mathrm{C})$, 126.7 ( $p$-Ph), 126.9 (o-Ph), 128.5 (o-Ar), $129.3(m-\mathrm{Ph}), 129.7$ (m-Ar), 136.6 (p-Ar), 137.7( $p$ - $\mathrm{Ph}$ ), 143.3 (ipso-Ar), 166.6 (C-3), 203.3 (CO); HRMS (ESI-TOF) $m / z\left[\mathrm{M}+\mathrm{NH}_{4}\right]^{+}$calcd for $\mathrm{C}_{24} \mathrm{H}_{35} \mathrm{~N}_{2} \mathrm{O}_{5} \mathrm{~S}$ 463.2261, found 463.2254.

Representative Experimental Procedures for the Intermolecular Michael/Aldol Cyclization/Intramolecular Aza-Michael Reaction. General Procedure A. PS-BEMP (1.0 equiv) was added to a solution of the $\beta$-keto ester (1.0 equiv) and Michael acceptor (1.1 equiv) in $i-\mathrm{PrOH}(4 \mathrm{~mL} / \mathrm{mmol})$, and the resulting mixture was stirred at room temperature for $72 \mathrm{~h}$. Filtration, evaporation of the solvent, and chromatography gave the corresponding octahydroindole product.

General Procedure B. To $\beta$-keto ester (1.0 equiv) and Michael acceptor (1.1 equiv) in toluene at $0{ }^{\circ} \mathrm{C}$ was added $\mathrm{LiOAc}$ ( 0.5 equiv) followed by pyrrolidine 3 ( 0.1 equiv), and the resulting mixture was stirred at $0{ }^{\circ} \mathrm{C}$ for $24 \mathrm{~h}$. The solvent was removed in vacuo and the residue dissolved in $i$-PrOH $(4 \mathrm{~mL} / \mathrm{mmol})$. PS-BEMP (1.0 equiv) was added, and the resulting mixture was stirred at room temperature for 72 h. Filtration, concentration, and chromatography gave the corresponding enantioenriched octahydroindole product.

General Procedure C. To $\beta$-keto ester (1.0 equiv) and Michael acceptor ( 1.1 equiv) in toluene at $0{ }^{\circ} \mathrm{C}$ was added $\mathrm{LiOAc}$ ( 0.5 equiv) 
followed by catalyst 3 ( 0.1 equiv), and the resulting mixture was stirred at $0{ }^{\circ} \mathrm{C}$ for $24 \mathrm{~h}$. The solvent was removed and the residue dissolved in $i$-PrOH $(4 \mathrm{~mL} / \mathrm{mmol}) . \mathrm{Pd} / \mathrm{C}(20 \% \mathrm{w} / \mathrm{w})$ was added, and the flask was fitted with a hydrogen balloon and hydrogenated until no enal was observed. The mixture was filtered through Celite, and the solvent was evaporated in vacuo. PS-BEMP (1.0 equiv) was then added, and the resulting mixture was stirred at room temperature for $72 \mathrm{~h}$. Filtration of the resin and chromatography gave the corresponding enantioenriched octahydroindole product.

rac-(3aR,6R,7aR)-tert-Butyl 4-Hydroxy-6-methyl-1-(4-methylphenylsulfonyl)-2,3,3a,6,7,7a-hexahydro-1H-indole-5-carboxylate (rac2a). Prepared according to general procedure A using crotonaldehyde (26 $\mu \mathrm{L}, 0.309 \mathrm{mmol})$, $\beta$-keto ester 1a $(100 \mathrm{mg}, 0.281 \mathrm{mmol})$, PSBEMP (130 mg, $0.286 \mathrm{mmol})$, and $i-\mathrm{PrOH}(1 \mathrm{~mL})$. Purification by chromatography (hexane to hexane/EtOAc 3:1) gave octahydroindole rac-2a (78 $\mathrm{mg}, 68 \%$ ) as a white solid: $\mathrm{mp} 131-132{ }^{\circ} \mathrm{C} ;{ }^{1} \mathrm{H}$ NMR $\left(\mathrm{CDCl}_{3}, 400 \mathrm{MHz}\right) \delta 1.10\left(\mathrm{~s}, 3 \mathrm{H}, \mathrm{CH}_{3}\right), 1.50\left(\mathrm{~s}, 9 \mathrm{H}, \mathrm{CH}_{3}\right), 1.60(\mathrm{td}, J$ $=12.8,5.2 \mathrm{~Hz}, 1 \mathrm{H}, \mathrm{H}-7 \mathrm{ax}), 1.90(\mathrm{qd}, J=12.0,8.0 \mathrm{~Hz}, 1 \mathrm{H}, \mathrm{H}-3 \beta), 2.02$ (ddd, $J=13.0,5.0,2.4 \mathrm{~Hz}, 1 \mathrm{H}, \mathrm{H}-7 \mathrm{eq}), 2.26(\mathrm{dt}, J=12.0,6.0 \mathrm{~Hz}, 1 \mathrm{H}$, $\mathrm{H}-3 \alpha$ ), 2.35 (ddd, $J=12.0,8.0,7.2 \mathrm{~Hz}, 1 \mathrm{H}, \mathrm{H}-3 \mathrm{a}), 2.44(\mathrm{~s}, 3 \mathrm{H}$, $\mathrm{ArCH}_{3}$ ), 2.72 (qdd, $J=7.2,2.8,2.0 \mathrm{~Hz}, 1 \mathrm{H}, \mathrm{H}-6 \mathrm{eq}$ ), 3.06 (ddd, $J=$ 12.0, 8.0, 6.0 Hz, $1 \mathrm{H}, \mathrm{H}-2 \alpha$ ), $3.58(\mathrm{t}, J=8.0 \mathrm{~Hz}, 1 \mathrm{H}, \mathrm{H}-2 \beta), 3.93$ (ddd, $J=12.8,8.0,4.8 \mathrm{~Hz}, 1 \mathrm{H}, \mathrm{H}-7 \mathrm{a}), 7.35$ (d, $2 \mathrm{H}, m-\mathrm{ArH}), 7.75$ (d, $2 \mathrm{H}, o-$ $\mathrm{ArH}) ;{ }^{13} \mathrm{C}$ NMR $\left(100 \mathrm{MHz}, \mathrm{CDCl}_{3}\right) \delta 20.5\left(\mathrm{CH}_{3}\right), 21.5\left(\mathrm{ArCH}_{3}\right)$, 27.5 (C-6), $28.2\left(\mathrm{CH}_{3}\right), 29.3$ (C-3), 34.9 (C-7), 41.5 (C-3a), 47.9 (C2), 55.0 (C-7a) 81.5 (C), 104.2 (C-5), 127.4 (o-Ar), 129.8 (m-Ar), 134.4 ( $p$-Ar), 143.5 (ipso-Ar), 169.0 (C-4), 171.9 (CO); HRMS (ESITOF) $m / z[\mathrm{M}+\mathrm{H}]^{+}$calcd for $\mathrm{C}_{21} \mathrm{H}_{30} \mathrm{NO}_{5} \mathrm{~S}$ 408.1839, found 408.1848.

(3aR,6R,7aR)-tert-Butyl 4-Hydroxy-6-methyl-1-(4-methylphenylsulfonyl)-2,3,3a,6,7,7a-hexahydro-1H-indole-5-carboxylate (2a). Prepared according to general procedure $\mathrm{B}$ using $\beta$-keto ester 1a (100 $\mathrm{mg}, 0.281 \mathrm{mmol})$, crotonaldehyde $(22 \mathrm{mg}, 0.309 \mathrm{mmol})$, catalyst 3 (14 mg, $0.028 \mathrm{mmol}$ ), LiOAc ( $9 \mathrm{mg}, 0.141 \mathrm{mmol})$, and toluene (1.0 $\mathrm{mL})$ at $0{ }^{\circ} \mathrm{C}$ for $24 \mathrm{~h}$ followed by cyclization with PS-BEMP $(128 \mathrm{mg}$, $0.281 \mathrm{mmol}$ ) and $i-\mathrm{PrOH}(1 \mathrm{~mL})$. Chromatography (hexane to hexane/EtOAc 1:1) gave octahydroindole $2 \mathrm{a}(57 \mathrm{mg}, 50 \%)$ as a white solid: $[\alpha]_{\mathrm{D}}+110.9\left(c 1, \mathrm{CHCl}_{3}\right)$. For analysis data, see the procedure for rac-2a.

(3aR,6R,7aR)-tert-Butyl 4-Hydroxy-6-ethyl-1-(4-methylphenylsulfonyl)-2,3,3a,6,7,7a-hexahydro-1H-indole-5-carboxylate (2b). Prepared according to general procedure B using trans-pentanal $(34 \mathrm{mg}$, $0.402 \mathrm{mmol}), \beta$-keto ester $1 \mathrm{a}(130 \mathrm{mg}, 0.366 \mathrm{mmol})$, organocatalyst 3 $(19 \mathrm{mg}, 0.037 \mathrm{mmol})$, and $\mathrm{LiOAc}(12 \mathrm{mg}, 0.183 \mathrm{mmol})$ in toluene $(1.4 \mathrm{~mL})$ at $0{ }^{\circ} \mathrm{C}$ for $24 \mathrm{~h}$ followed by cyclization with PS-BEMP (166 $\mathrm{mg}, 0.366 \mathrm{mmol}$ ) and $i-\mathrm{PrOH}(1 \mathrm{~mL})$. Chromatography (hexane to hexane/EtOAc 3:1) gave octahydroindole $2 \mathrm{~b}(78 \mathrm{mg}, 51 \%)$ as a yellow oil: ${ }^{1} \mathrm{H}$ NMR $\left(\mathrm{CDCl}_{3}, 400 \mathrm{MHz}\right) \delta 0.98(\mathrm{t}, J=7.4 \mathrm{~Hz}, 3 \mathrm{H}$, $\left.\mathrm{CH}_{3}\right), 1.19-1.28\left(\mathrm{~m}, 1 \mathrm{H}, \mathrm{H} 6-\mathrm{CH}_{2}\right), 1.38-1.44(\mathrm{~m}, 1 \mathrm{H}, \mathrm{H}-7), 1.49$ (s, $\left.9 \mathrm{H}, \mathrm{CH}_{3}\right), 1.50-1.57\left(\mathrm{~m}, 1 \mathrm{H}, \mathrm{H} 6-\mathrm{CH}_{2}\right) 1.89$ (ddd, $J=19.6,11.6,7.6$ $\mathrm{Hz}, 1 \mathrm{H}, \mathrm{H}-3 \beta$ ), 2.20 (ddd, $J=4.7,2.4 \mathrm{~Hz}, 1 \mathrm{H}, \mathrm{H}-7 \mathrm{eq}), 2.21-2.29$ (m, $1 \mathrm{H}, \mathrm{H}-3 \alpha$ ), 2.32-2.40 (m, 1H, H-6), 2.43 (s, 3H, $\mathrm{ArCH}_{3}$ ), 2.41-2.48 (m, $1 \mathrm{H}, \mathrm{H}-3 \mathrm{a}$ ), 3.05 (ddd, $J=11.6,9.6,6.4 \mathrm{~Hz}, 1 \mathrm{H}, \mathrm{H}-2 \alpha$ ), 3.58 (ddd, $J=9.1,7.8,1.0 \mathrm{~Hz}, 1 \mathrm{H}, \mathrm{H}-2 \beta$ ), 3.86 (ddd, $J=12.8,8.2,4.8 \mathrm{~Hz}, 1 \mathrm{H}, \mathrm{H}-$ 7a), 7.32 (d, $J=7.9 \mathrm{~Hz}, 2 \mathrm{H}, m-\mathrm{ArH}), 7.72(\mathrm{~d}, J=8.3 \mathrm{~Hz}, 2 \mathrm{H}, o-\mathrm{ArH})$; ${ }^{13} \mathrm{C}$ NMR $\left(100 \mathrm{MHz}, \mathrm{CDCl}_{3}\right) \delta 12.8\left(\mathrm{CH}_{3}\right), 21.6\left(\mathrm{ArCH}_{3}\right), 27.4$ $\left(\mathrm{CH}_{2}\right), 28.3\left(\mathrm{CH}_{3}\right), 29.5$ (C-3), 30.8 (C-7), 34.3 (C-6), 41.5 (C-3a), 48.0 (C-2), 55.1 (C-7a) 81.6 (C), 104.0 (C-5), 127.5 (o-Ar), 129.9 (mAr), 134.4 (p-Ar), 143.6 (ipso-Ar), 169.4 (C-4), 172.1 (CO); HRMS (ESI-TOF) $\mathrm{m} / z[\mathrm{M}+\mathrm{H}]^{+}$calcd for $\mathrm{C}_{22} \mathrm{H}_{32} \mathrm{NO}_{5} \mathrm{~S} 422.2005$, found 422.1996.

(3aS,6S,7aS)-tert-Butyl 6-Heptyl-4-hydroxy-1-(4-methylphenylsulfonyl)-2,3,3a,6,7,7a-hexahydro-1H-indole-5-carboxylate (2c). Prepared according to general procedure $\mathrm{C}$ using $\beta$-keto ester 1a (100 mg, $0.281 \mathrm{mmol})$, trans-2-decenal $(57 \mu \mathrm{L}, 0.309 \mathrm{mmol})$, catalyst 3 (15 mg, $0.028 \mathrm{mmol})$, and LiOAc ( $9 \mathrm{mg}, 0.140 \mathrm{mmol})$ in toluene (1 $\mathrm{mL}$ ). Chromatography (hexane to hexane/EtOAc 1:1) gave octahydroindole $2 \mathrm{c}(55 \mathrm{mg}, 40 \%)$ as a white solid: $\mathrm{mp} 118-121$ ${ }^{\circ} \mathrm{C} ;{ }^{1} \mathrm{H}$ NMR (400 MHz, $\left.\mathrm{CDCl}_{3}\right) \delta 0.91\left(\mathrm{t}, J=6.8 \mathrm{~Hz}, 3 \mathrm{H}, \mathrm{CH}_{3}\right)$, 1.15-1.40 (m, 12H, H-alkyl), 1.41-1.50 (m, 1H, H-7), $1.50(\mathrm{~s}, 9 \mathrm{H}$,
$\mathrm{CH}_{3}$ ), 1.88 (dddd, $J=12.0,12.0,12.0,8.0 \mathrm{~Hz}, 1 \mathrm{H}, \mathrm{H}-3$ ) 2.19 (ddd, $J=$ 13.2, 4.4, $2.4 \mathrm{~Hz}, 1 \mathrm{H}, \mathrm{H}-7$ ), 2.27 (ddd, $J=12.4,6.4,6.4 \mathrm{~Hz}, 1 \mathrm{H}, \mathrm{H}-3$ ), $2.37(\mathrm{dt}, J=12.0,7.6 \mathrm{~Hz}, 1 \mathrm{H}, \mathrm{H}-3 \mathrm{a}), 2.44\left(\mathrm{~s}, 3 \mathrm{H}, \mathrm{ArCH}_{3}\right), 2.49-2.57$ (m, 1H, H-6), 3.06 (ddd, $J=11.2,9.6,6.4 \mathrm{~Hz}, 1 \mathrm{H}, \mathrm{H}-2), 3.58$ (dd, $J=$ $8.8,8.8 \mathrm{~Hz}, 1 \mathrm{H}, \mathrm{H}-2$ ), 3.86 (ddd, $J=12.8,8.4,4.8 \mathrm{~Hz}, 1 \mathrm{H}, \mathrm{H}-7 \mathrm{a}$ ), 7.32 $(\mathrm{d}, J=8.0 \mathrm{~Hz}, 2 \mathrm{H}, m-\mathrm{ArH}), 7.71(\mathrm{~d}, J=8.4 \mathrm{~Hz}, 2 \mathrm{H}, o-\operatorname{ArH}), 12.4(\mathrm{~s}$, $1 \mathrm{H}$, enal); ${ }^{13} \mathrm{C} \mathrm{NMR}\left(100 \mathrm{MHz}, \mathrm{CDCl}_{3}\right) \delta 14.1\left(\mathrm{CH}_{3}\right.$ side chain $)$, 21.5 $\left(\mathrm{ArCH}_{3}\right), 22.7\left(\mathrm{CH}_{2}\right.$-alkyl), $27.8\left(\mathrm{CH}_{2}-\right.$ alkyl $), 28.2\left(\mathrm{CH}_{3} t-\mathrm{Bu}\right)$, $29.26\left(\mathrm{CH}_{2}\right.$-alkyl), $29.33\left(\mathrm{CH}_{2}\right.$-alkyl), 29.6 (C-3), 30.9 (C-7), 31.9 ( $\mathrm{CH}_{2}$-alkyl), 32.3 (C-6), 34.2 ( $\mathrm{CH}_{2}-$ alkyl), 41.4 (C-3a), 47.9 (C-2), 54.9 (C-7a), 81.5 (C t-Bu), 104.0 (C-5), 127.4 (o-Ar), 129.7 (m-Ar), 134.3 (p-Ar), 143.5 (ipso-Ar), 169.2 (C-4), 172.0 (CO); HRMS (ESITOF) $m / z[\mathrm{M}+\mathrm{H}]^{+}$calcd for $\mathrm{C}_{27} \mathrm{H}_{42} \mathrm{NO}_{5} \mathrm{~S} 492.2778$, found 492.2779.

(3aS,6R,7aS)-tert-Butyl 4-Hydroxy-6-(2-hydroxyethyl)-1-(4-methylphenylsulfonyl)-2,3,3a,6,7,7a-hexahydro- $1 \mathrm{H}$-indole-5-carboxylate (rac-2d). Prepared according to general procedure A using (E)-5hydroxypent-2-enal ${ }^{27}(17 \mathrm{mg}, 0.171 \mathrm{mmol}), \beta$-keto ester $1 \mathrm{a}(55 \mathrm{mg}$, $0.155 \mathrm{mmol})$, PS-BEMP $(70 \mathrm{mg}, 0.155 \mathrm{mmol})$, and $i-\mathrm{PrOH}(0.6 \mathrm{~mL})$. Chromatography (hexane to hexane/EtOAc 1:1) gave octahydroindole rac-2d (42 mg, 61\%) as a yellow oil: ${ }^{1} \mathrm{H}$ NMR (400 MHz, $\left.\mathrm{CDCl}_{3}\right) \delta 1.52\left(\mathrm{~s}, 9 \mathrm{H}, \mathrm{CH}_{3}\right), 1.53-1.62\left(\mathrm{~m}, 2 \mathrm{H}, \mathrm{H}-7\right.$ and $\left.\mathrm{H}-\mathrm{1}^{\prime}\right), 1.71-$ $1.79\left(\mathrm{~m}, 1 \mathrm{H}, \mathrm{H}-1^{\prime}\right) 1.90$ (ddd, $\left.J=12.0,4.0 \mathrm{~Hz}, 1 \mathrm{H}, \mathrm{H}-3\right), 2.19$ (ddd, $J$ $=4.8,2.4 \mathrm{~Hz}, 1 \mathrm{H}, \mathrm{H}-7 \mathrm{eq}), 2.25-2.32(\mathrm{~m}, 1 \mathrm{H}, \mathrm{H}-3 \alpha), 2.37-2.42(\mathrm{~m}$, 1H, H-3a), 2.44 (s, 3H, $\mathrm{ArCH}_{3}$ ), 2.69-2.75 (m, 1H, H-6), 3.04 (ddd, $J$ $=11.2,9.6,6.4 \mathrm{~Hz}, 1 \mathrm{H}, \mathrm{H}-2 \alpha), 3.58(\mathrm{ddd}, J=9.2,7.6,0.8 \mathrm{~Hz}, 1 \mathrm{H}, \mathrm{H}-$ $2 \beta), 3.67-3.78\left(\mathrm{~m}, 2 \mathrm{H}, \mathrm{H}-2^{\prime}\right), 3.93$ (ddd, $J=13.2,8.4,4.8 \mathrm{~Hz}, 1 \mathrm{H}, \mathrm{H}-$ $7 \mathrm{a}), 7.32$ (d, $J=7.9 \mathrm{~Hz}, 2 \mathrm{H}, m-\operatorname{ArH}), 7.72(\mathrm{~d}, J=8.3 \mathrm{~Hz}, 2 \mathrm{H}, o-\operatorname{ArH}$ ); ${ }^{13} \mathrm{C} \mathrm{NMR}\left(100 \mathrm{MHz}, \mathrm{CDCl}_{3}\right) \delta 21.7\left(\mathrm{ArCH}_{3}\right), 28.4\left(\mathrm{CH}_{3}\right), 29.4(\mathrm{C}-$ 3), 29.5 (C-6), 32.2 (C-7), 37.6 (C-1'), 41.6 (C-3a), 48.0 (C-2), 55.1 (C-7a), 61.4 (C-2'), 82.3 (C), 103.3 (C-5), 127.6 (o-Ar), 129.9 (m$\mathrm{Ar}$ ), 134.3 (p-Ar), 143.8 (ipso-Ar), 170.1 (C-4), 171.9 (CO); HRMS (ESI-TOF) $\mathrm{m} / z[\mathrm{M}+\mathrm{H}]^{+}$calcd for $\mathrm{C}_{22} \mathrm{H}_{32} \mathrm{NO}_{6} \mathrm{~S} 438.1949$, found 438.1945 .

(3aR,6R,7aR)-tert-Butyl 4-Hydroxy-1-(4-methylphenylsulfonyl)-6phenyl-2,3,3a,6,7,7a-hexahydro-1H-indole-5-carboxylate (2e). Prepared according to general procedure $\mathrm{C}$ using cinnamaldehyde (23 $\mathrm{mg}, 0.176 \mathrm{mmol}), \beta$-keto ester 1a $(57 \mathrm{mg}, 0.160 \mathrm{mmol})$, organocatalyst $3(8 \mathrm{mg}, 0.016 \mathrm{mmol})$, and LiOAc $(5 \mathrm{mg}, 0.080 \mathrm{mmol})$ in toluene $(0.5 \mathrm{~mL})$. Chromatography (hexane to hexane/EtOAc 1:1) gave octahydroindole $2 \mathrm{e}(36 \mathrm{mg}, 41 \%)$ as a white solid: $\mathrm{mp} 168-170$ ${ }^{\circ} \mathrm{C} ;{ }^{1} \mathrm{H}$ NMR $\left(400 \mathrm{MHz} \mathrm{CDCl}_{3}\right) \delta 1.23\left(\mathrm{~s}, 9 \mathrm{H}, \mathrm{CH}_{3}\right), 1.89-1.97(\mathrm{~m}$, $1 \mathrm{H}, \mathrm{H}-7 \mathrm{ax}), 1.90-1.98(\mathrm{~m}, 1 \mathrm{H}, \mathrm{H}-3 \beta), 2.17-2.20(\mathrm{~m}, 1 \mathrm{H}, \mathrm{H}-7 \mathrm{eq})$, 2.90-2.26 (m, 1H, H-3 $\alpha$ ), 2.41-2.51 (m, $1 \mathrm{H}, \mathrm{H}-3 \mathrm{a}), 2.41(\mathrm{~s}, 3 \mathrm{H}$, $\left.\mathrm{ArCH}_{3}\right), 3.08(\mathrm{td}, J=10.1,6.6 \mathrm{~Hz}, 1 \mathrm{H}, \mathrm{H}-2 \alpha), 3.54-3.58(\mathrm{~m}, 1 \mathrm{H}, \mathrm{H}-$ 7a), 3.58 (ddd, $J=12.0,9.6,7.6,2.0 \mathrm{~Hz}, 1 \mathrm{H}, \mathrm{H}-2 \beta), 3.90(\mathrm{t}, J=8.8 \mathrm{~Hz}$, $1 \mathrm{H}, \mathrm{H}-6 \mathrm{eq}), 7.07$ (d, $J=7.2 \mathrm{~Hz}, 2 \mathrm{H}, m-\mathrm{Ph}), 7.22(\mathrm{~d}, J=8.0 \mathrm{~Hz}, 2 \mathrm{H}, o-$ $\mathrm{Ph}), 7.28(\mathrm{~d}, J=8.0 \mathrm{~Hz}, 2 \mathrm{H}, m-\mathrm{ArH}), 7.60(\mathrm{~d}, J=8.4 \mathrm{~Hz}, 2 \mathrm{H}, o-\mathrm{ArH})$; ${ }^{13} \mathrm{C} \mathrm{NMR}\left(100 \mathrm{MHz}, \mathrm{CDCl}_{3}\right) \delta 21.5\left(\mathrm{ArCH}_{3}\right), 27.8\left(\mathrm{CH}_{3}\right), 28.8(\mathrm{C}-$ 3), 35.7 (C-7), 38.5 (C-6), 41.8 (C-3a), 48.2 (C-2), 54.7 (C-7a) 81.6 (C), 101.7 (C-5), 126.0 (o-Ph), $127.2(m-\mathrm{Ph}), 127.4$ (o-Ar), 128.1 ( $p$ $\mathrm{Ph}) 129.6$ (m-Ar), 133.7 (p-Ar), 143.4 (ipso-Ar), 144.1 (ipso-Ph), 170.7 (C-4), 171.7 (CO); HRMS (ESI-TOF) $\mathrm{m} / z[\mathrm{M}+\mathrm{H}]^{+}$calcd for $\mathrm{C}_{26} \mathrm{H}_{32} \mathrm{NO}_{5} \mathrm{~S} 470.2001$, found 470.1996 .

(3aS,6R,7aS)-tert-Butyl 6-(4-Chlorophenyl)-4-hydroxy-1-(4-methylphenylsulfonyl)-2,3,3a,6,7,7a-hexahydro- $1 \mathrm{H}$-indole-5-carboxylate (2f). Prepared according to general procedure $C$ using 4chlorocinnamaldehyde $(33 \mathrm{mg}, 0.198 \mathrm{mmol}), \beta$-keto ester 1a (64 $\mathrm{mg}, 0.180 \mathrm{mmol})$, organocatalyst $3(9 \mathrm{mg}, 0.018 \mathrm{mmol})$, and LiOAc (6 $\mathrm{mg}, 0.090 \mathrm{mmol})$ in toluene $(0.7 \mathrm{~mL})$. Chromatography (hexane to hexane/EtOAc 1:1) gave octahydroindole $2 \mathrm{f}(39 \mathrm{mg}, 43 \%)$ as a white solid: $\mathrm{mp} 185-187^{\circ} \mathrm{C}$; ${ }^{1} \mathrm{H}$ NMR $\left(400 \mathrm{MHz}, \mathrm{CDCl}_{3}\right) \delta 1.24(\mathrm{~s}, 9 \mathrm{H}$, $\mathrm{CH}_{3}$ ), 1.89-2.00 (m, 2H, H-7ax, H-3 $\beta$ ), $2.14(\mathrm{dt}, J=7.6,3.6 \mathrm{~Hz}, 1 \mathrm{H}$, H-7eq), 2.22 (dtd, $J=13.6,8.8,6.8 \mathrm{H}, \mathrm{H}-3 \alpha), 2.42\left(\mathrm{~s}, 3 \mathrm{H}, \mathrm{ArCH}_{3}\right)$, 2.44-2.52 (m, 1H, H-3a), 3.08 (dt, $J=10.0,6.4 \mathrm{~Hz}, 1 \mathrm{H}, \mathrm{H}-2 \alpha), 3.47-$ $3.53(\mathrm{~m}, 1 \mathrm{H}, \mathrm{H}-6), 3.88(\mathrm{t}, J=4.8 \mathrm{~Hz}, 1 \mathrm{H}, \mathrm{H}-2 \beta), 7.03(\mathrm{~d}, J=8.4 \mathrm{~Hz}$, $2 \mathrm{H}, o-\mathrm{Ar}$ ), 7.25 (d, $J=8.8 \mathrm{~Hz}, 2 \mathrm{H}, m-\mathrm{Ar}), 7.27(\mathrm{~d}, J=6.4 \mathrm{~Hz}, 2 \mathrm{H}, o-$ $\mathrm{Ph}$ ), 7.48 (d, $J=8.0 \mathrm{~Hz}, 2 \mathrm{H}, m-\mathrm{Ph}) ;{ }^{13} \mathrm{C}$ NMR $\left(100 \mathrm{MHz}, \mathrm{CDCl}_{3}\right) \delta$ $21.6\left(\mathrm{ArCH}_{3}\right), 28.0\left(\mathrm{CH}_{3}\right), 28.9(\mathrm{C}-3), 35.9(\mathrm{C}-7), 38.2$ (C-6), 41.9 (C-3a), 48.3 (C-2), 54.7 (C-7a), 82.0 (C), 101.4 (C-5), 127.6 (o-Ar), 
128.4 (o-Ph), 128.7 ( $m$-Ph), 129.8 (m-Ar), 131.9 ( $p-\mathrm{Ph}), 133.8$ (p-Ar), 143.0 (ipso-Ar), 143.8 (ipso-Ph), 170.9 (C-4), 171.6 (CO); HRMS (ESI-TOF) $m / z[\mathrm{M}+\mathrm{H}]^{+}$calcd for $\mathrm{C}_{26} \mathrm{H}_{31} \mathrm{ClNO}_{5} \mathrm{~S} 504.1606$, found 504.1609.

(3aR,6R,7aR)-tert-Butyl 4-Hydroxy-6-(methoxyphenyl)-1-(4methylphenylsulfonyl)-2,3,3a,6,7,7a-hexahydro-1H-indole-5-carboxylate (2g). Prepared according to general procedure $\mathrm{C}$ using trans4-methoxycinnamaldehyde $(29 \mathrm{mg}, 0.179 \mathrm{mmol}), \beta$-keto ester $1 \mathrm{a}(58$ $\mathrm{mg}, 0.163 \mathrm{mmol})$, catalyst $3(8 \mathrm{mg}, 0.016 \mathrm{mmol})$, and LiOAc (5 mg, $0.082 \mathrm{mmol})$ in toluene $(0.5 \mathrm{~mL})$. Chromatography (hexane to hexane/EtOAc 1:1) gave octahydroindole $2 \mathrm{~g}(32 \mathrm{mg}, 40 \%)$ as a white solid: $\mathrm{mp} 152-154{ }^{\circ} \mathrm{C}$; ${ }^{1} \mathrm{H}$ NMR $\left(400 \mathrm{MHz}, \mathrm{CDCl}_{3}\right) \delta 1.25(\mathrm{~s}, 9 \mathrm{H}$, $\left.\mathrm{CH}_{3}\right), 1.87(\mathrm{td}, J=12.8,7.6 \mathrm{~Hz}, 1 \mathrm{H}, \mathrm{H}-7 \mathrm{ax}), 1.90-2.00(\mathrm{~m}, 1 \mathrm{H}, \mathrm{H}-$ $3 \beta$ ), 2.16 (dt, $J=8.0,4.0 \mathrm{~Hz}, 1 \mathrm{H}, \mathrm{H}-7 \mathrm{eq}), 2.23$ (ddd, $J=14.0,8.4,6.8$ $\mathrm{H}, \mathrm{H}-3 \alpha$ ), 2.41 (s, 3H, $\mathrm{ArCH}_{3}$ ), 2.42-2.49 (m, 1H, H-3a), 3.07 (dt, J $=10.0,6.4 \mathrm{~Hz}, 1 \mathrm{H}, \mathrm{H}-2 \alpha), 3.56-3.62(\mathrm{~m}, 2 \mathrm{H}, \mathrm{H}-6$ and $\mathrm{H}-2 \beta), 3.83(\mathrm{~s}$, $\left.3 \mathrm{H}, \mathrm{CH}_{3}\right), 3.86(\mathrm{dd}, J=5.2,2.8 \mathrm{~Hz}, 1 \mathrm{H}, \mathrm{H}-7 \mathrm{a}), 6.83(\mathrm{~d}, J=8.8 \mathrm{~Hz}$, $2 \mathrm{H}, o-\mathrm{Ph}$ ), 6.99 (d, $J=8.8 \mathrm{~Hz}, 2 \mathrm{H}, o-\mathrm{Ar}), 7.23(\mathrm{~d}, J=8.0 \mathrm{~Hz}, 2 \mathrm{H}, m-$ Ar), 7.48 (d, $J=8.4 \mathrm{~Hz}, 2 \mathrm{H}, m-\mathrm{Ph}) ;{ }^{13} \mathrm{C}$ NMR $\left(100 \mathrm{MHz}, \mathrm{CDCl}_{3}\right) \delta$ $21.5\left(\mathrm{ArCH}_{3}\right), 27.9\left(\mathrm{CH}_{3}\right), 28.9$ (C-3), 35.9 (C-7), 37.7 (C-6), 41.7 (C-3a), 48.2 (C-2), 54.7 (C-7a), $55.3\left(\mathrm{OCH}_{3}\right), 81.6(\mathrm{C}), 101.8$ (C-5), 113.5 (o-Ph), 127.4 (o-Ar), 128.1 ( $m$-Ph), 129.6 (m-Ar), 133.7 ( $p$-Ar), 136.2 ( $p$-Ph), 143.4 (ipso-Ar), 157.8 (ipso-Ph), 170.3 (C-4), 171.7 (CO); HRMS (ESI-TOF) $m / z[\mathrm{M}+\mathrm{H}]^{+}$calcd for $\mathrm{C}_{27} \mathrm{H}_{34} \mathrm{NO}_{6} \mathrm{~S}$ 500.2103, found 500.2101.

(2R,3aS,6S,7aS)-tert-Butyl 2-Benzyl-4-hydroxy-6-methyl-1-(4methylphenylsulfonyl)-2,3,3a,6,7,7a-hexahydro-1H-indole-5-carboxylate (4a). Prepared according to general procedure A using $\beta$ keto ester $1 \mathrm{~b}$ (190 mg, $0.426 \mathrm{mmol})$, crotonaldehyde $(36 \mathrm{mg}, 0.511$ mmol), PS-BEMP (194 mg, $0.426 \mathrm{mmol}$ ), and $i$-PrOH $(2 \mathrm{~mL})$. Chromatography (hexane to hexane/EtOAc 1:1) gave octahydroindole $4 \mathrm{a}(105 \mathrm{mg}, 44 \%)$ as a colorless oil: $[\alpha]_{\mathrm{D}}-6.7\left(c 1, \mathrm{CHCl}_{3}\right) ;{ }^{1} \mathrm{H}$ $\operatorname{NMR}\left(400 \mathrm{MHz}, \mathrm{CDCl}_{3}\right) \delta 1.07\left(\mathrm{~d}, J=7.2 \mathrm{~Hz}, 3 \mathrm{H}, \mathrm{CH}_{3}\right), 1.24-1.27$ (m, 1H, H-7ax), 1.47 (s, 9H, $\left.\mathrm{CH}_{3}\right), 1.62-1.72(\mathrm{~m}, 1 \mathrm{H}, \mathrm{H}-3), 1.77$ (ddd, $J=13.2,4.8,2.0 \mathrm{~Hz}, 1 \mathrm{H}, \mathrm{H}-7 \mathrm{eq}) 1.98-2.04(\mathrm{~m}, 1 \mathrm{H}, \mathrm{H}-3 \mathrm{a})$, 2.12-2.18 (m, 1H, H-3), 2.44 (s, 3H, $\mathrm{ArCH}_{3}$ ), 2.61 (qdd, $J=7.2,5.6$, $2.4 \mathrm{~Hz}, 1 \mathrm{H}, \mathrm{H}-6$ ), 2.94 (dd, $J=13.2,8.8 \mathrm{~Hz}, 1 \mathrm{H}, \mathrm{CH}_{2} \mathrm{Ph}$ ), 3.40 (dd, $J$ $\left.=13.2,3.2 \mathrm{~Hz}, 1 \mathrm{H}, \mathrm{CH}_{2} \mathrm{Ph}\right), 3.67-3.74(\mathrm{~m}, 1 \mathrm{H}, \mathrm{H}-2), 3.98$ (ddd, $J=$ 12.5, 7.8, $4.8 \mathrm{~Hz}, 1 \mathrm{H}, \mathrm{H}-7 \mathrm{a}), 7.21-7.35(\mathrm{~m}, 7 \mathrm{H}, \mathrm{ArH}), 7.78(\mathrm{~d}, J=8.3$ $\mathrm{Hz}, 2 \mathrm{H}, o-\mathrm{ArH}) ;{ }^{13} \mathrm{C}$ NMR $\left(100 \mathrm{MHz}, \mathrm{CDCl}_{3}\right) \delta 20.7\left(\mathrm{CH}_{3}\right), 21.7$ $\left(\mathrm{ArCH}_{3}\right), 27.5$ (C-6), $28.4\left(\mathrm{CH}_{3}\right), 34.8$ (C-7), 35.8 (C-3), 40.3 (C3a), $43.1\left(\mathrm{CH}_{2}-\mathrm{Ph}\right), 56.9$ (C-7a), 62.2 (C-2), 81.7 (C), 104.0 (C-5), 126.7 (o-Ph), 127.6 (o-Ar), 128.4 (m-Ph), 130.0 (m-Ar), 130.1 ( $p$-Ph), 134.6 ( $p$-Ar), 137.7 (Ph), 143.9 (ipso-Ar), 169.3 (C-4), 172.1 (CO); HRMS (ESI-TOF) $\mathrm{m} / z[\mathrm{M}+\mathrm{H}]^{+}$calcd for $\mathrm{C}_{28} \mathrm{H}_{36} \mathrm{NO}_{5} \mathrm{~S} 498.2309$, found 498.2293 .

(2R,3aS,6S,7aS)-tert-Butyl 2-Benzyl-6-heptyl-4-hydroxy-1-(4methylphenylsulfonyl)-2,3,3a,6,7,7a-hexahydro-1H-indole-5-carboxylate $(\mathbf{4 b})$. Prepared according to general procedure $\mathrm{A}$ using $\beta$ keto ester $1 \mathbf{b}(100 \mathrm{mg}, 0.224 \mathrm{mmol})$, trans-2-decenal $(46 \mu \mathrm{L}, 0.246$ $\mathrm{mmol})$, PS-BEMP (102 mg, $0.225 \mathrm{mmol})$, and $i-\mathrm{PrOH}(1 \mathrm{~mL})$. Chromatography (hexane to hexane/EtOAc 1:1) gave octahydroindole $4 \mathbf{b}(36 \mathrm{mg}, 28 \%)$ as a colorless oil: $[\alpha]_{\mathrm{D}}-12.7\left(c 1, \mathrm{CHCl}_{3}\right) ;{ }^{1} \mathrm{H}$ NMR (400 MHz, $\left.\mathrm{CDCl}_{3}\right) \delta 0.83-0.92\left(\mathrm{~m}, 3 \mathrm{H}, \mathrm{CH}_{3}\right.$ alkyl), $1.10-1.18$ (m, 1H, H-7), 1.18-1.38 (m, 12H, $\mathrm{CH}_{2}$ alkyl), 1.47 (s, 9H, $\left.\mathrm{CH}_{3}\right), 1.67$ (ddd, $J=12.4,12.4,10.4 \mathrm{~Hz}, 1 \mathrm{H}, \mathrm{H}-3$ ), 1.93 (ddd, $J=13.2,4.8,2.4$ Hz, 1H, H-7),2.04 (ddd, $J=12.4,7.6,7.2 \mathrm{~Hz}, 1 \mathrm{H}, \mathrm{H}-3 \mathrm{a}$ ), 2.16 (ddd, $J$ $=12.4,7.2,6.8 \mathrm{~Hz}, 1 \mathrm{H}, \mathrm{H}-3), 2.38-2.46(\mathrm{~m}, 1 \mathrm{H}, \mathrm{H}-6), 2.44(\mathrm{~s}, 3 \mathrm{H}$, $\left.\mathrm{ArCH}_{3}\right), 2.93\left(\mathrm{dd}, J=13.2,9.2 \mathrm{~Hz}, 1 \mathrm{H}, \mathrm{CH}_{2} \mathrm{Ph}\right), 3.42(\mathrm{dd}, J=13.2$, $3.2 \mathrm{~Hz}, 1 \mathrm{H}, \mathrm{CH}_{2} \mathrm{Ph}$ ), 3.65-3.75 (m, $\left.1 \mathrm{H}, \mathrm{H}-2\right), 3.91$ (ddd, $J=12.8,8.0$, $4.8 \mathrm{~Hz}, 1 \mathrm{H}, \mathrm{H}-7 \mathrm{a}), 7.20-7.36(\mathrm{~m}, 7 \mathrm{H}, \mathrm{ArH}), 7.76(\mathrm{~d}, J=8.4 \mathrm{~Hz}, 2 \mathrm{H}$, $m$-Ar); ${ }^{13} \mathrm{C}$ NMR $\left(100 \mathrm{MHz}, \mathrm{CDCl}_{3}\right) \delta 14.1\left(\mathrm{CH}_{3}\right.$ alkyl), 21.5 $\left(\mathrm{ArCH}_{3}\right), 22.7\left(\mathrm{CH}_{2}\right.$ alkyl $) 27.8\left(\mathrm{CH}_{2}\right.$ alkyl $), 28.2\left(\mathrm{CH}_{3} t-\mathrm{Bu}\right), 29.3$ ( $\mathrm{CH}_{2}$ alkyl), $29.6\left(\mathrm{CH}_{2}\right.$ alkyl), 30.7 (C-7), $31.9\left(\mathrm{CH}_{2}\right.$ alkyl), 32.2 (C6), $34.2\left(\mathrm{CH}_{2}\right.$ alkyl), $35.8(\mathrm{C}-3), 40.0(\mathrm{C}-3 \mathrm{a}), 42.9\left(\mathrm{CH}_{2} \mathrm{Ph}\right), 56.8(\mathrm{C}-$ 7a), 62.0 (C-2), 81.5 (C $t$-Bu), 103.5 (C-5), 126.5, 127.5, 128.3, 129.8, $129.9,134.5,137.6,143.7,169.4$ (C-4), 172.0 (CO); HRMS (ESITOF) $m / z[\mathrm{M}+\mathrm{H}]^{+}$calcd for $\mathrm{C}_{34} \mathrm{H}_{48} \mathrm{NO}_{5} \mathrm{~S}$ 582.3253, found 582.3262 .
(2R,3aS,6R,7aS)-tert-Butyl 2-Benzyl-4-hydroxy-6-(2-hydroxyethyl)-1-(4-methylphenylsulfonyl)-2,3,3a,6,7,7a-hexahydro-1H-indole5 -carboxylate (4c). Prepared according to general procedure A using $\beta$-keto ester $\mathbf{1 b}(56 \mathrm{mg}, 0.126 \mathrm{mmol}),(E)$-5-hydroxypent-2-enal (14 $\mathrm{mg}, 0.138 \mathrm{mmol})$, PS-BEMP (57 mg, $0.126 \mathrm{mmol})$, and $i$-PrOH $(0.5$ $\mathrm{mL}$ ). Purification by chromatography (hexane to hexane/EtOAc $1: 1$ ) gave octahydroindole $4 \mathrm{c}(20 \mathrm{mg}, 30 \%)$ as a colorless oil: $[\alpha]_{\mathrm{D}}-17.1(c$ $\left.1, \mathrm{CHCl}_{3}\right) ;{ }^{1} \mathrm{H} \mathrm{NMR}\left(400 \mathrm{MHz}, \mathrm{CDCl}_{3}\right) \delta 1.14-121\left(\mathrm{~m} \mathrm{1H}, \mathrm{H}-1^{\prime}\right)$, $1.48-1.56(\mathrm{~m}, 1 \mathrm{H}, \mathrm{H}-3), 1.49\left(\mathrm{~s}, 9 \mathrm{H}, \mathrm{CH}_{3}\right), 1.64-1.74(\mathrm{~m}, 1 \mathrm{H}, \mathrm{H}-3)$, 1.91-1.95 (dm, 1H, H-1' $)$, 2.04-2.10 (m, 1H, H-3a), 2.14-2.20 (m, $1 \mathrm{H}, \mathrm{H}-7), 2.44$ (s, 3H, $\left.\mathrm{ArCH}_{3}\right), 2.60-2.62(\mathrm{~m}, 1 \mathrm{H}, \mathrm{H}-6), 2.95$ (dd, $J=$ 13.6, $\left.8.8 \mathrm{~Hz}, 1 \mathrm{H}, \mathrm{CH}_{2} \mathrm{Ph}\right), 3.40\left(\mathrm{dd}, J=13.6,3.2 \mathrm{~Hz}, 1 \mathrm{H}, \mathrm{CH}_{2} \mathrm{Ph}\right)$, 3.61-3.75 (m, 3H, H-2, H-2'), 3.97 (ddd, $J=12.4,7.2,4.4 \mathrm{~Hz}, 1 \mathrm{H}, \mathrm{H}-$ $7 \mathrm{a}), 7.21-7.35(\mathrm{~m}, 5 \mathrm{H}, \mathrm{ArH}), 7.35(\mathrm{~d}, J=8.0 \mathrm{~Hz}, 2 \mathrm{H}, o-\mathrm{Ar}), 7.77$ (d, $J$ $=8.0 \mathrm{~Hz}, 2 \mathrm{H}, m-\mathrm{Ar}) ;{ }^{13} \mathrm{C} \mathrm{NMR}\left(100 \mathrm{MHz}, \mathrm{CDCl}_{3}\right) \delta 21.7\left(\mathrm{ArCH}_{3}\right)$, $28.4\left(\mathrm{CH}_{3}\right), 29.3$ (C-6), $31.9\left(\mathrm{C}-1^{\prime}\right), 35.9$ (C-7), 37.6 (C-3), 40.1 (C3a), $42.8\left(\mathrm{CH}_{2}-\mathrm{Ph}\right), 57.0(\mathrm{C}-7 \mathrm{a}), 61.4\left(\mathrm{C}-2^{\prime}\right), 62.2(\mathrm{C}-2), 82.3(\mathrm{C})$, 102.9 (C-5), 126.7, 127.6, 128.4, 130.1, 130.2, 134.4, 137.6, 144.0, 170.1 (C-4), 171.9 (CO); HRMS (ESI-TOF) $m / z[\mathrm{M}+\mathrm{H}]^{+}$calcd for $\mathrm{C}_{29} \mathrm{H}_{38} \mathrm{NO}_{6} \mathrm{~S}$ 528.2434, found 528.2414.

(2R,3aS,6R,7aS)-tert-Butyl 2-Benzyl-4-hydroxy-1-(4-methylphenylsulfonyl)-6-phenyl-2,3,3a,6,7,7a-hexahydro-1H-indole-5-carboxylate $(4 d)$. Prepared according to general procedure A using $\beta$-keto ester $1 \mathbf{b}(49 \mathrm{mg}, 0.110 \mathrm{mmol})$, cinnamaldehyde $(16 \mathrm{mg}, 0.121 \mathrm{mmol})$, PS-BEMP $(50 \mathrm{mg}, 0.110 \mathrm{mmol})$, and $i-\mathrm{PrOH}(0.4 \mathrm{~mL})$. Chromatography (hexane to hexane/EtOAc 1:1) gave octahydroindole 4d (26 $\mathrm{mg}, 43 \%)$ as a white solid: $\mathrm{mp} 145-147^{\circ} \mathrm{C}$; $[\alpha]_{\mathrm{D}}-46.8\left(c 1, \mathrm{CHCl}_{3}\right)$; ${ }^{1} \mathrm{H}$ NMR $\left(400 \mathrm{MHz}, \mathrm{CDCl}_{3}\right) \delta 1.19\left(\mathrm{~s}, 9 \mathrm{H}, \mathrm{CH}_{3}\right), 1.49-1.55(\mathrm{~m}, 1 \mathrm{H}$, $\mathrm{H}-3), 1.71-1.81(\mathrm{~m}, 1 \mathrm{H}, \mathrm{H}-7) 1.88(\mathrm{dt}, J=13.2,7.2,3.2 \mathrm{~Hz}, 1 \mathrm{H}, \mathrm{H}-$ 3), $2.11-2.20(\mathrm{~m}, 2 \mathrm{H}, \mathrm{H}-7, \mathrm{H}-3 \mathrm{a}), 2.42\left(\mathrm{~s}, 3 \mathrm{H}, \mathrm{ArCH}_{3}\right), 2.96(\mathrm{dd}, J=$ $\left.13.2,8.8 \mathrm{~Hz}, 1 \mathrm{H}, \mathrm{CH}_{2} \mathrm{Ph}\right), 3.38\left(\mathrm{dd}, J=13.2,2.8 \mathrm{~Hz}, 1 \mathrm{H}, \mathrm{CH}_{2} \mathrm{Ph}\right)$, 3.63 (ddd, $J=12.0,7.6,4.4 \mathrm{~Hz}, 1 \mathrm{H}, \mathrm{H}-7 \mathrm{a}), 3.72-3.84$ (m, 2H, H-2, H6), $7.01(\mathrm{~d}, J=7.6 \mathrm{~Hz}, 2 \mathrm{H}, o-\mathrm{Ar}), 7.21-7.35(\mathrm{~m}, 10 \mathrm{H}, \mathrm{ArH}), 7.49$ (d, $=8.0 \mathrm{~Hz}, 2 \mathrm{H}, m-\mathrm{Ar}) ;{ }^{13} \mathrm{C} \mathrm{NMR}\left(100 \mathrm{MHz}, \mathrm{CDCl}_{3}\right) \delta 21.7\left(\mathrm{ArCH}_{3}\right)$, $28.0\left(\mathrm{CH}_{3}\right), 34.9$ (C-7), 35.5 (C-3), 38.8 (C-6), 40.4 (C-3a), 42.9 $\left(\mathrm{CH}_{2}-\mathrm{Ph}\right), 56.4$ (C-7a), 62.5 (C-2), 81.7 (C), 101.2 (C-5), 126.2, $126.7127 .3,127.6128 .2,128.3,128.6,128.8,129.8,130.0,130.2$, 134.0, 137.7, 143.8, 144.2, 170.9 (C-4), 171.8 (CO); HRMS (ESITOF) $m / z[\mathrm{M}+\mathrm{H}]^{+}$calcd for $\mathrm{C}_{33} \mathrm{H}_{38} \mathrm{NO}_{5} \mathrm{~S} 560.2469$, found 560.2465 .

\section{ASSOCIATED CONTENT}

\section{S Supporting Information}

The Supporting Information is available free of charge on the ACS Publications website at DOI: 10.1021/acs.joc.6b01568.

Analytical data and copies of HPLC and ${ }^{1} \mathrm{H}$ and ${ }^{13} \mathrm{C}$ NMR spectra of the new compounds; Cartesian coordinates and energies for all species considered in Figure 4 (PDF)

\section{AUTHOR INFORMATION}

\section{Corresponding Authors}

*E-mail: josep.bonjoch@ub.edu.

*E-mail: benbradshaw@ub.edu.

\section{Author Contributions}

${ }^{\S}$ ISHC member.

\section{Notes}

The authors declare no competing financial interest.

\section{ACKNOWLEDGMENTS}

Financial support for this research was provided by the Projects CTQ2013-41338-P and CTQ2013-47925_C2 from MINECO (the Ministry of Economy and Competitiveness of Spain) and the FP7 Marie Curie Actions of the European Commission via the ITN ECHONET Network (MCITN-2012-316379). C.P. is a recipient of a predoctoral fellowship (CONICYT, Chile). We 
also thank IZO-SGI SGlker of UPV/EHU for their technical and human support.

\section{REFERENCES}

(1) For reviews of organocatalysis in the synthesis of natural products, see: (a) Marqués-López, E.; Herrera, R. P.; Christmann, M. Nat. Prod. Rep. 2010, 27, 1138-1167. (b) Abbasov, M. E.; Romo, D. Nat. Prod. Rep. 2014, 31, 1318-1327. (c) Sun, B.-F. Tetrahedron Lett. 2015, 56, 2133-2140. (d) Ishikawa, H.; Shiomi, S. Org. Biomol. Chem. 2016, 14, 409-424.

(2) Bradshaw, B.; Luque-Corredera, C.; Bonjoch, J. Org. Lett. 2013, $15,326-329$.

(3) Bradshaw, B.; Luque-Corredera, C.; Bonjoch, J. Chem. Commun. 2014, 50, 7099-7102.

(4) For a mechanistic study of the reaction, see: Bradshaw, B.; Luque-Corredera, C.; Saborit, G.; Cativiela, C.; Dorel, R.; Bo, C.; Bonjoch, J. Chem. - Eur. J. 2013, 19, 13881-13892.

(5) Bradshaw, B.; Parra, C.; Bonjoch, J. Org. Lett. 2013, 15, 24582461.

(6) We have recently become aware of a new approach to hydroindoles through organocatalysis from acyclic precursors. Cossío, F. P. (XXVI Reunión Bienal GEQOR, Punta Umbría, Spain) Personal communication, June 2016.

(7) For total syntheses, see: (a) Valls, N.; Lopez-Canet, M.; Vallribera, M.; Bonjoch, J. J. Am. Chem. Soc. 2000, 122, 11248-11249.

(b) Dailler, D.; Danoun, G.; Baudoin, O. Angew. Chem., Int. Ed. 2015, 54, 4919-4922 and references cited therein.

(8) For total synthesis, see: Ghavre, M.; Froese, J.; Pour, M.; Hudlicky, T. Angew. Chem., Int. Ed. 2016, 55, 5642-5691 and references cited therein.

(9) For its isolation, see: Zhang, H.; Yang, S.-P.; Fan, C.-Q.; Ding, J.; Yue, J.-M. J. Nat. Prod. 2006, 69, 553-557.

(10) Frankowski, K. J.; Golden, J. E.; Zeng, Y.; Lei, Y.; Aubé, J. J. Am. Chem. Soc. 2008, 130, 6018-6024.

(11) Hurst, M.; Jarvis, B. Drugs 2001, 61, 867-896.

(12) (a) Sayago, F. J.; Laborda, P.; Calaza, M. I.; Jiménez, A. I.; Cativiela, C. Eur. J. Org. Chem. 2011, 2011, 2011-2028. (b) Arceo, E.; Jurberg, I. D.; Alvarez-Fernández, A.; Melchiorre, P. Nat. Chem. 2013, $5,750-756$.

(13) (a) Wipf, P.; Kim, Y.; Goldstein, D. M. J. Am. Chem. Soc. 1995, 117, 11106-11112. (b) Bonjoch, J.; Catena, J.; Isábal, E.; LópezCanet, M.; Valls, N. Tetrahedron: Asymmetry 1996, 7, 1899-1902.

(c) Hanessian, S.; Tremblay, M. Org. Lett. 2004, 6, 4683-4686.

(d) Ruff, B. M.; Zhong, S.; Nieger, M.; Sickert, M.; Schneider, C.; Bräse, S. Eur. J. Org. Chem. 2011, 2011, 6558-6566. (e) Hanessian, S.; Dorich, S.; Menz, H. Org. Lett. 2013, 15, 4134-4137.

(14) (a) Schindler, C. S.; Diethelm, S.; Carreira, E. M. Angew. Chem., Int. Ed. 2009, 48, 6296-6299. (b) Trost, B. M.; Kaneko, T.; Andersen, N. G.; Tappertzhofen, C.; Fahr, B. J. Am. Chem. Soc. 2012, 134, 18944-18947. (c) Sun, Z.; Zhou, M.; Li, X.; Meng, X.; Peng, F.; Zhang, H.; Shao, Z. Chem. - Eur. J. 2014, 20, 6112-6119. (d) Dailler, D.; Danoun, G.; Baudoin, O. Angew. Chem., Int. Ed. 2015, 54, 49194922.

(15) Using aminocatalysis: (a) Pantaine, L.; Coeffard, V.; Moreau, X.; Greck, C. Org. Lett. 2015, 17, 3674-3677. Using a chiral Brönsted acid catalyst: (b) Ruff, B. M.; Zhong, S.; Nieger, M.; Sickert, M.; Schneider, C.; Bräse, S. Eur. J. Org. Chem. 2011, 2011, 6558-6566. (c) Han, Y.; Zheng, B.; Peng, Y. Adv. Synth. Catal. 2015, 357, 11361142 .

(16) For a general overview of the organocatalytic intramolecular azaMichael reaction, see: Sánchez-Roselló, M.; Aceña, J. L.; SimónFuentes, A.; del Pozo, C. Chem. Soc. Rev. 2014, 43, 7430-7453.

(17) Johnston, C. P.; Kothari, A.; Sergeieva, T.; Okovytyy, S. I.; Jackson, K. E.; Paton, R. S.; Smith, M. D. Nat. Chem. 2015, 7, 171177.

(18) For reaction of $N$-tosylaziridines with dianions derived from $\beta$ keto esters, see: Lygo, B. Synlett 1993, 1993, 764-766.

(19) Chong, B.; Ji, Y.; Oh, S.; Yang, J.; Baik, W.; Koo, S. J. Org. Chem. 1997, 62, 9323-9325.
(20) Hagiwara, H.; Okabe, T.; Ono, H.; Kamat, V. P.; Hoshi, T.; Suzuki, T.; Ando, M. J. Chem. Soc. Perkin Trans. 1 2002, 895-900.

(21) Pilling, A. W.; Boehmer, J.; Dixon, D. J. Angew. Chem., Int. Ed. 2007, 46, 5428-5430.

(22) Other conditions evaluated without improvement include the use of BEMP without solid support, the addition of water (10 equiv) to PS-BEMP ( 1 equiv), and variations in the quantities and reaction times employed with Amberlyst-26.

(23) Palomo, C.; Landa, A.; Mielgo, A.; Oiarbide, M.; Puente, A.; Vera, S. Angew. Chem., Int. Ed. 2007, 46, 8431-8435.

(24) Jensen, K. L.; Dickmeiss, G.; Jiang, H.; Albrecht, L.; Jørgensen, K. A. Acc. Chem. Res. 2012, 45, 248-264.

(25) For diastereoselective construction of remote stereocenters, see: (a) Hayashi, R.; Walton, M. C.; Hsung, R. P.; schwab, J. H.; Yu, X. Org. Lett. 2010, 12, 5768-5771. (b) Aron, Z. D.; Ito, T.; May, T. L.; Overman, L. E.; Wang, J. J. Org. Chem. 2013, 78, 9929-9948. (c) Kwon, K.-H.; Serrano, C. M.; Koch, M.; Barrows, L. R.; Looper, R. E. Org. Lett. 2014, 16, 6048-6051. (d) Kobayakawa, T.; Narumi, T.; Tamamura, H. Org. Lett. 2015, 17, 2302-2305.

(26) For further details, see the Supporting Information.

(27) Zhang, W.; Bah, J.; Wohlfarth, A.; Franzén, J. Chem. - Eur. J. 2011, 17, 13814-13824. 